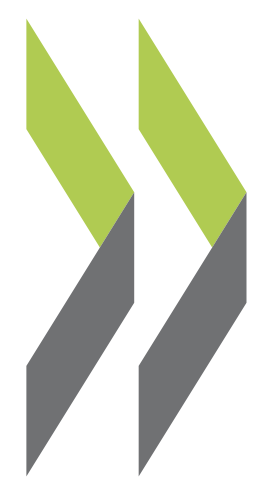

OECD Science, Technology and Industry Working Papers 1996/08

\title{
The Evolution of Skills in OECD Countries and the Role of Technology
}


STI WORKING PAPERS

1996/8

THE EVOLUTION OF SKILLS IN OECD COUNTRIES AND THE ROLE OF TECHNOLOGY

A. Colecchia and G. Papaconstantinou

ORGANISATION FOR ECONOMIC CO-OPERATION AND DEVELOPMENT

Paris

46222

Document complet disponible sur OLIS dans son format d'origine

Complete document available on OLIS in its original format 


\section{STI Working Papers Series}

This Working Papers series of the OECD Directorate for Science, Technology and Industry of the OECD is designed to make available to a wider readership selected studies prepared by staff in the Directorate or by outside consultants working on OECD projects. The papers included in the series are of a technical and analytical nature and deal with issues of data, methodology and empirical analysis in the areas of work of DSTI. The Working Papers are generally available only in their original language - English or French with a summary in the other.

Comment on the papers is invited, and should be sent to Directorate for Science, Technology and Industry, OECD, 2 rue André Pascal, 75775 Paris Cedex 16, France.

The opinions expressed in these papers are the sole responsibility of the author(s) and do not necessarily reflect those of the OECD or of the governments of its Member countries.

\section{Copyright OECD, 1996}

Applications for permission to reproduce or translate all or part of this material should be made to:

Head of Publications Service, OECD, 2 rue André Pascal, 75775 Paris, Cedex 16, France. 


\title{
The Evolution of Skills in OECD Countries and the Role of Technology
}

\author{
A. Colecchia and G. Papaconstantinou*
}

The aim of this paper is two-fold: to highlight stylised facts about recent trends in the skill distribution of employment and to analyse the role that technological change might have in explaining these dynamics. Data on industrial employment broken down by occupation recently assembled by the OECD Secretariat are used to examine the changing skill composition of OECD economies, the occupational structure of industry and services, and the dynamics of upskilling. They show that in most OECD countries during the 1980s, employment grew fastest in high-skilled jobs and slowest - or declined - in low-skilled jobs. The upskilling trend is more apparent in manufacturing than in services, while overall the shift to higher skilled jobs has occurred primarily within industries, rather than between them. Econometric work that explores the role of technology in the changing skill mix in five of the G7 countries in the 1980s shows that upskilling has occurred faster in industries that have higher than average $R \& D$ expenditures and growth rates in the number of patents. Moreover, human capital has accumulated faster in those sectors which were more intensive in the use of high skilled workers at the beginning of the 1980s.

L'objectif de ce document est double : mettre en évidence les grandes lignes de l'évolution récente de la structure de l'emploi par niveau de qualification et analyser le rôle que peuvent y jouer les mutations technologiques. Les données sur l'emploi industriel ventilées par profession, récemment réunies par le Secrétariat de l'OCDE, permettent d'examiner l'évolution de la structure des économies de l'OCDE par niveau de qualification, la structure professionnelle des industries et des services et la dynamique du relèvement des qualifications. Ces données font apparaître que dans la plupart des pays de l'OCDE, au cours des années 80 , l'emploi s'est accru plus rapidement dans les professions hautement qualifiées et plus lentement - dans les professions peu qualifiées - lorsqu'il n'a pas reculé. Le relèvement des qualifications est plus patent dans les industries manufacturières que dans les services, mais dans l'ensemble cette évolution au profit des emplois plus qualifiés est intervenue essentiellement à l'intérieur des secteurs d'activité plutôt que d'un secteur à l'autre. L'analyse économétrique consacrée au rôle de la technologie dans l'évolution de la répartition des qualifications dans cinq des pays Membres du G7 dans les années 80 montrent que le relèvement des qualifications a été plus rapide dans les secteurs où les dépenses de R-D et le taux de croissance du nombre de brevets déposés sont supérieurs à la moyenne. En outre, l'accumulation de capital humain a été plus rapide dans les secteurs qui, au début des années 80 , ont fait davantage appel à des travailleurs hautement qualifiés.

* Economic Analysis and Statistics Division, Directorate for Science, Technology and Industry/Division des analyses économiques et des statistiques, Direction de la science, de la technologie et de l'industrie

e-mail addresses: alessandra.colecchia@oecd.org george.papaconstantinou@ oecd.org 


\section{TABLE OF CONTENTS}

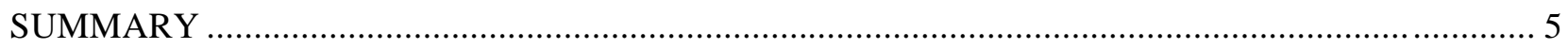

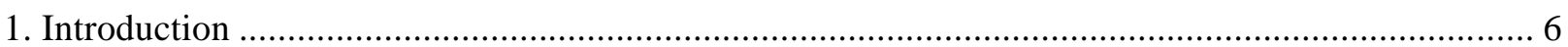

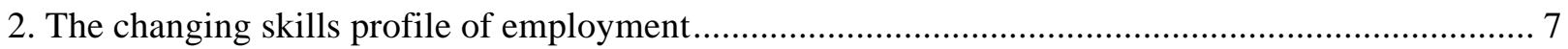

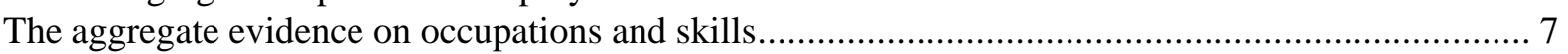

The sectoral evidence: occupational shifts in industry and the services ......................................... 9

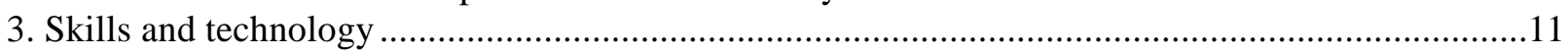

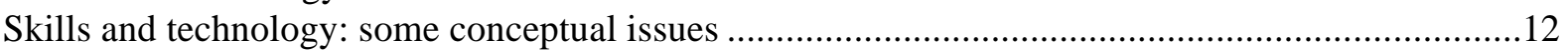

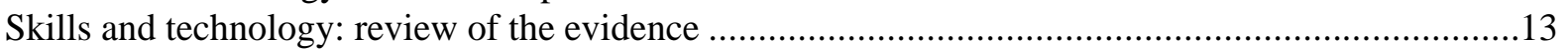

The accumulation of human capital and the role of technology investment and diffusion..................16

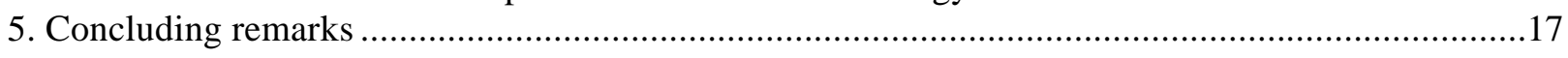

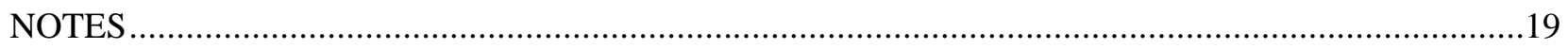

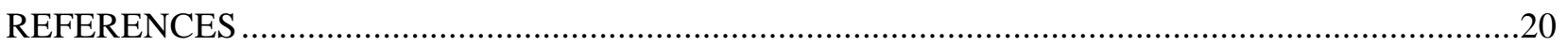

Graph 1. Employment growth for blue- and white-collar workers over the 1980s .................................22

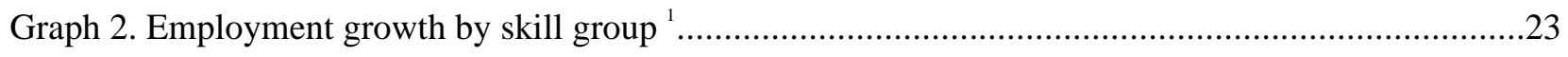

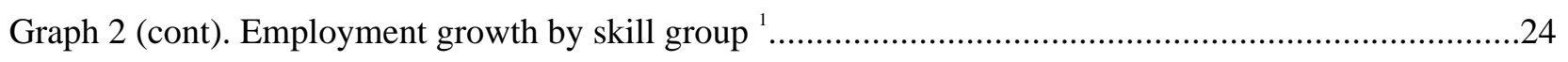

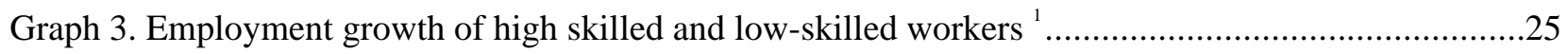

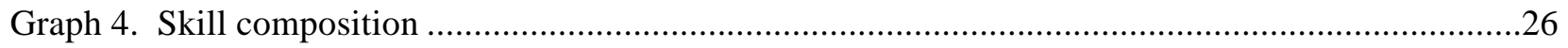

Graph 5. Employment growth breakdown by skill level in manufacturing and services ..........................27

Graph 6. Breakdown of manufactuting employment growth by skills and levels of technology ...............28

Graph 7. Breakdown of services employment growth by occupations..................................................29

Table 1. Percentage of labour force with "high" and "low" education...................................................32

Table 3. Decomposition of changes in high-skilled employment ${ }^{1}$.........................................................34

Table 4 - Upskilling and technology: cross-sector regressions (France, Italy, Japan, US, Germany)..........35

Table 5 - The growth rate of high skilled workers in the 80s: cross-sector regressions (France, Italy, Japan, US, Germany) 


\section{SUMMARY}

The aim of this paper is two-fold: to highlight stylised facts about recent trends in the skill distribution of employment and to analyse the role that technological change might have in explaining these dynamics. Data on industrial employment broken down by occupation recently assembled by the OECD Secretariat are used to examine the changing skill composition of OECD economies, the occupational structure of industry and services, and the dynamics of upskilling. These data are then used in econometric work that explores the role of technology in the changing skill mix.

Changes in the occupational distribution of employment give one measure of the changing skills structure of jobs. In most OECD countries during the 1980s, employment grew fastest in high-skilled jobs and slowest - or declined - in low-skilled jobs.

Within the white collar group of occupations, high-skilled jobs have tended to show the fastest growth. Within the blue-collar group of workers, high-skilled jobs have declined in most countries, while bluecollar low-skilled ones show a more diverse picture by country. Despite these trends, the majority of occupations remain low-skilled (accounting for between two-thirds and three-quarters of the total, depending on the country), but the share of high-skilled occupations is steadily rising in all countries.

Underlying the overall upskilling trend, which can be observed in OECD countries at the level of total employment, is a contrasting evolution in manufacturing and in the services. It is in manufacturing where the upskilling trend is most apparent: while overall manufacturing employment has declined in most countries, white collar high-skilled manufacturing jobs have continued to increase and blue-collar lowskilled ones have shown the steepest decline.

In contrast, in the services, where overall employment growth has been robust, white collar low-skilled jobs have increased almost as fast as white collar high-skilled ones, with blue-collar high-skilled jobs showing the weakest growth.

Overall, most of the shift away from unskilled and towards skilled employment reflects a true upskilling process rather than a change in the industrial composition of economies: shifts have occurred primarily within industries, rather than between them. This is true both in manufacturing and in the services, but particularly in manufacturing.

The role of technology in explaining upskilling trends is examined with the help of cross-sectoral regressions for 22 manufacturing industrial sectors in five of the G7 countries (Canada and UK excluded) in the 1980s. The results show that upskilling has occurred faster in industries that have higher than average $R \& D$ expenditures and growth rates in the number of patents.

Moreover, human capital has accumulated faster in those sectors which were more intensive in the use of high skilled workers at the beginning of the 1980s. Human capital accumulation and innovative efforts can be read as a joint process which renforces in a cumulative way and can create some phenomena of persistence in industrial performance.

The paper also presents some preliminary results concerning the impact of technology investment and diffusion on the growth rate of employment of high skilled workers. The impact of R\&D flows on the accumulation of human capital is examined through different channels, and a distinction is made between direct $R \& D$ expenditure and $R \& D$ diffusion through domestic and foreign spillovers. 


\section{Introduction}

Technological change has greatly altered the demand for worker skills. Many tasks once carried out manually are now performed by automated equipment, and the demand for certain skills has disappeared as the demand for new skills has emerged. In parallel, the level of education of workers has increased markedly in all OECD countries. Today, as information-based technologies, such as computers and sophisticated machine tools, become more widespread, certain skills may be less in demand, while the demand for workers able to maintain, program, and develop these sophisticated technologies rise. There is therefore concern that technological change may increase the polarisation of society by widening the gap in income and employment opportunities between those whose skills have been displaced by new technology and those who create and use it.

While it is generally agreed that the introduction of new technologies requires new skills, there is considerable debate about the extent to which technological change is responsible for decreased demand for low-skilled workers. From an empirical point of view there has been a lack of detailed data on both worker skills and technology. While many countries have recently collected information on new technologies, particularly information technologies, and on worker skills at the firm level, aggregate comparable data across countries are lacking. From a theoretical point of view the question is complex and requires analysis in a framework that can account for all the factors that affect the demand for and the supply of workers with different skills.

The principal reason for the increased concern over how technological change is altering the demand for various skills is the sharp decline (some authors have used the word "collapse") in the demand for lowskilled workers, combined with an increase in the demand for highly skilled workers. In economies with flexible labour markets, such as the United States and the United Kingdom, the decrease in demand for low-skilled workers has resulted in an increasing wage differential between skilled and unskilled workers. In countries with more rigid labour markets, the drop in demand has manifested itself in greater unemployment of low-skilled workers.

Against this background, the aim of this paper is two-fold: to highlight stylised facts about recent trends in the skill distribution of employment and to analyse the role that technological change might have in explaining these dynamics. With respect to the first, the paper uses data on industrial employment broken down by occupation recently assembled by the OECD Secretariat in order to examine the changing skill composition of OECD economies, the occupational structure of industry and services industries, and the dynamics of upskilling. These data are then used in econometric work that explores the role of technology in the changing skill mix.

The structure of the paper is as follows. Section 2 examines the changing skills profile of employment at the aggregate and sectoral level. In particular, it examines trends in occupations in OECD countries in the 1970s and 1980s, the occupational distribution of employment in individual industries and in broad segments of the economy, and the dynamics of upskilling, by decomposing the employment growth in individual industries to that due to the growth or decline of different occupations within each industry. This allows also an analysis of the importance of industrial compositional shifts vs. that of occupational shifts in the overall evolution of employment in OECD countries. Section 3 reviews the ongoing debate about the impact of technology, international trade and other factors on the demand for unskilled labour in OECD countries and presents some results on the impact of technology on the changing share of highskilled workers. Concluding remarks are in section 4. 


\section{The changing skills profile of employment}

This section reviews changes in the skills profile of employment in OECD countries during the 1970s and 1980s, a period during which the relative supply of skilled workers was increasing. In most OECD countries, employment conditions for unskilled workers deteriorated, especially during the 1980s. Nickell and Bell (1995) have documented this phenomenon for the OECD area as a whole; various other studies analyse more than one country (Davis, 1992; Katz et al, 1993; Freeman, 1994; Goux and Maurin, 1995), while still others examine individual industrialised countries. It is generally argued that the decrease in the demand for low-skilled workers is felt either as an increase in the wage differential between skilled and unskilled workers, or as increased unemployment of low-skilled workers (e.g. Glyn, 1995).

\section{The aggregate evidence on occupations and skills}

The 1980s saw an upskilling in the labour force of OECD countries, as demonstrated by changes in the educational level of workers (for a discussion of the concept of skill and how to measure it, see Box 1). Table 1 shows the evolution of the labour force in 12 countries in terms of low and high levels of education. College graduates are generally taken to have a high level of education while those with a basic qualification or less are taken to have a low level. The table shows that the educational level of the work force has been significantly upgraded, owing to a marked decrease in the portion of the work force with low education and large increases in the share of workers with high education, while in the 1980s, skilled workers increased more rapidly in France, Germany, Sweden, and Australia than in the United States.

Upskilling within economies is also revealed by changes in employment by occupation, and it is on this measure of skills that this paper concentrates. White-collar workers dominate overall employment, and their share in the total has increased during the 1970s and 1980s in all countries. In absolute terms, Graph 1 shows annual growth rates in employment of white-collar and blue-collar workers during the 1980s and through the early 1990s for 18 countries. Many countries saw a decrease in the number of blue-collar occupations, and all countries saw an increase in white-collar employment, with the largest increases in latecomers to industrialisation such as Mexico, Portugal, Greece, Ireland, and Spain.

More detail on changes in the occupational distribution of employment are given in Table 2. Over the 1980s, employment grew fastest in white-collar jobs (professional, administrative and managerial, clerical and sales) and slowest - or declined - in blue-collar jobs (transport and production workers and labourers), a trend that can be observed in most OECD countries. Within the white collar group, employment has grown most rapidly in the "professional and technical" and the "administrative and managerial" groups of occupations. Given however the relatively large weight of clerical and sales workers in the total, a substantial number of jobs has continued to be created in these occupations despite the increasing use of new technologies and in particular IT in many services industries.

The information provided to the OECD from a number of countries allows an aggregation of occupations into four categories which describe the broad evolution of the occupations mix in economies over time: white collar high-skilled (WCHS, comprising legislators, senior officials \& managers, professionals, and technicians \& associate professionals); white collar low-skilled (WCLS - clerks and service workers, shop \& market sales workers); blue-collar high-skilled (BCHS - skilled agricultural \& fishery workers, craft \& related trades workers); and blue collar low-skilled (BCLS - plant and machine operators \& assemblers, elementary occupations). 


\section{Box 1. Skills and how to measure them}

The term "skill" refers to the qualifications needed to perform certain tasks in the labour market. In the most general sense, it reflects the level of human capital in the labour markets, and upskilling can be seen as synonymous with human capital development. It is a multi-dimensional concept, since most jobs require a multitude of skills for adequate task performance, ranging from physical abilities like eye-hand coordination, dexterity and strength, to cognitive skills (analytic and synthetic reasoning, numerical and verbal abilities) and interpersonal (supervisory, leadership) skills (Wolff, 1996).

In empirical work, researchers often use proxies based on education and occupation. Education is usually categorised by years of schooling or final degree obtained, and is not adjusted for quality. Occupations sometimes provide more information on the skills required of workers, but measures vary considerably across countries and may be ambiguous. These measures do not necessarily take into account on-the-job learning, and, in particular, skills associated with the use of new technology. In practice, most empirical work that attempts to compare the evolution of skills internationally uses crude proxies such as the ratio of production and non-production workers, that of blue- and white-collar workers, or the share of the work force with a higher education qualification. Furthermore, these distinctions are typically only available at the aggregate level, and not at the level of individual industries.

This report uses a new dataset on occupations collected by the OECD Secretariat which improves on previous measures of skills in two ways: it incorporates a finer distinction between different skill level; and it can distinguish between skill levels in different industries. The occupational data are based on the new version of the International Standard Classification of Occupations of the International Labour Office, ISCO-88. Underlying the occupational categories in this classification are different levels of educational attainment, and this allows a proxy of different skill levels to be constructed, something which was not possible with other occupational classifications.

In the cases where data were available in ISCO-88 format, occupations were aggregated at different levels in the two following way:

- White-collar high-skilled (WCHS): Legislators, senior officials and managers (Group 1), Professionals (Group 2), Technicians and associate professionals (Group 3)

- White-collar low-skilled (WCLS): Clerks, service workers (Group 4), Shop \& market sales workers (Group 5)

- Blue-collar high-skilled (BCHS): Skilled agricultural and fishery workers (Group 6), Craft \& related trade workers (Group 7)

- Blue-collar low-skilled (BCLS): Plant \& machine operators and assemblers (Group 8), Elementary occupations (Group 9)

In the text, the white-collar high-skilled group is often referred to as "high-skilled", with all three remaining groups as "low-skilled". When data in national classifications were too aggregated to reclassify into ISCO-88 or when data was in ISCO-68 or obtained from the ILO Yearbook, a simple bluecollar/white-collar categorisation based on 1-digit ISCO-68 categories was used:

- White collar: Professional and technical (Groups 0/1), Administrative and managerial (Group 2), Clerical and related workers (Group 3), Sales workers (Group 4), Service workers (Group 5)

- Blue collar: Agricultural workers (Group 6), Transport/production workers, labourers (Groups 7/8/9) 
For the countries for which such data are available, Graph 2 suggests that it is the white collar high-skilled grouping that has tended to show the fastest growth, followed by the white collar low-skilled group. Blue collar high-skilled jobs have declined in most countries (the exception is the US), while blue collar low skilled ones show a more varied picture, ranging from decline (Canada, France, Italy, New Zealand) to stability or weak growth (Japan, Australia, the US). For large OECD countries, Graph 3 presents a twoway split of occupations into skilled (comprising only white collar high-skilled workers) and unskilled (the rest). It shows that, employment of high skilled workers has increased faster than that of low-skilled workers, at an average growth rate of 2-3 per cent during the 1980s. Low-skilled jobs have increased in Canada, Japan and the US, and a little in Italy, while declining in France. ${ }^{1}$

Graph 4 uses the ratios WCHS/WCLS, BCHS/BCLS, and WCHS/BCLS to identify the main common trends in occupational change in OECD economies. The ratio of high-skilled to low-skilled occupations within the white collar jobs group has only slightly increased throughout the 1980s. In the case of bluecollar occupations, low-skilled jobs decreased at a slower pace than high-skilled ones, resulting in consistently lower ratios, except in the case of the US, where blue-collar high-skilled jobs are growing faster than blue collar low-skilled ones. Finally, the WCHS/BCLS ratio has been the fastest growing throughout all countries. Comparisons of these ratios between countries reveal lower ratios for North America than Oceania or European countries. The results indicate some restructuring away from blue collar high-skilled jobs, although there is no direct evidence for declining skill levels of workers, given the consistent expansion of white-collar high-skilled employment levels.

\section{The sectoral evidence: occupational shifts in industry and the services}

Structural shifts, such as the increasing importance of services in overall employment and the decline in manufacturing jobs are major factors in the change in the occupational structure of the work force. At the same time, shifts within individual industries seem to have played an important role, and a growing literature tries to quantify these inter- and intra-industry effects (Berman et al., 1994). In general, the generation and diffusion of new technologies, shifts in the composition of final demand, and changes in the labour supply all underlie such changes, even though it is hard to disentangle the impact of each.

Broadly speaking, two main trends can be observed throughout all countries: a constant increase in the share of professional employees, especially within services; and a general decrease in the share of blue collar workers in both manufacturing and services. In the services sector, professional employees accounted in the early 1990s for over one fifth of total employment in Finance, Insurance, Real estate \& Business services (FIRB), and over one third in Community, Social and Personal Services (CSPS). FIRB has traditionally been a high-technology sector with large shares of high skilled jobs, while employment in CSPS has only recently begun to shift from clerical (Australia, Italy, Netherlands), service (Germany, Sweden) and elementary (Denmark, New Zealand) jobs, towards high skilled occupations. In manufacturing, professional occupations have gained relative weight in high technology industries, reaching a share of over 10 per cent in most countries.

The decrease in blue collar shares in both manufacturing and services suggests restructuring within industries, independently of the structural transformation towards higher employment in services, experienced by all OECD economies. In the early 1990s, the elementary occupations and plant $\&$ machine operators \& assemblers groups each accounted, on average, for less than 10 per cent of total employment. Elementary occupations experienced decreasing shares in high technology manufacturing (Australia, Denmark, Netherlands, United States), and in the case of New Zealand, in services sectors such as CSPS and Transport, storage and communications (TSC). Craft and related trades workers still accounted for an average of 15 per cent of total employment, but their share has been decreasing in both services. 
For the OECD area as a whole, clear patterns begin to emerge within industries as regards occupational distributions, in both expanding and contracting sectors. In manufacturing, the overall trend (more evident in the high-technology sectors) is towards increasing shares of employment for white-collar high-skilled workers, and decreasing ones for blue-collar low-skilled workers. Managerial positions have increased their share (Canada, Netherlands, New Zealand), as have professionals (Canada, Ireland) and technical \& associate professionals (France, Italy). On the other hand, plant \& machine operators (Canada, France) and elementary occupations (Australia) have lost significant shares, averaging only one fourth of total employment in high technology manufacturing in the early 1990 s.

The two service sectors which have recently contributed most to employment growth (FIRB and CSPS) have experienced two similar trends in almost every country: a rapid increase in professional jobs; and constant increase in managerial jobs. In the case of FIRB, clerical positions have tended to lose employment shares, while in CSPS the trend is mixed: in Australia, Austria and the Netherlands clerical jobs have declined, while in Ireland and New Zealand, they tend to increase (the share of clerks within CSPS is close to 15 per cent in every country). Service workers have also undergone a mixed trend with slight decreases in FIRB (Mexico, Netherlands, Sweden) but different shifts within CSPS: shares increased in Oceania, but decreased in Austria, Sweden and Mexico.

Upskilling and deskilling trends in manufacturing and in the services can be examined by looking at the growth or decline of the various occupations in each sector. Graph 5 presents the results of such a breakdown for the countries for which the available data permit the calculations. For manufacturing, it shows that the decline in employment is overwhelmingly associated with a decline in blue-collar lowskilled jobs (France, Germany, Australia, the United States) and, in two cases, in blue-collar high-skilled ones (Italy, New Zealand). In practically all countries where manufacturing employment declined, whitecollar high-skilled manufacturing jobs actually increased (the exception is New Zealand). In the services, the employment increase in all countries entails increases in both high- and low-skilled white-collar jobs.

Upskilling within manufacturing can be studied by looking at the changing role of different occupations in manufacturing employment growth or decline. Graph 6 breaks down changes due to the growth or decline of different occupational groups in employment in high-, medium- and low-technology manufacturing industries in five of the G7 countries. It shows that in every industry where employment has grown, whitecollar high-skilled job creation has contributed significantly. At the same time, where employment has declined (most cases), white-collar high-skilled jobs have continued to increase (the only exception is German low-technology industries). Conversely, blue-collar low-skilled jobs have declined in every country and every type of manufacturing industry, with the exception of Japanese high-technology industries, where there was remarkable job expansion in the 1980s.

The occupational composition of services is different from that of industry. Blue-collar workers predominate in manufacturing, even if their share in the total has been declining, but white-collar workers are in the majority in services and are rising as a share of the total. Behind this aggregate picture, however, and because of the heterogeneity of services, occupational distribution is not uniform in different segments. Thus, in wholesale and in retail trade, white-collar low-skilled jobs tend to dominate; in transport, storage, and communications services, blue-collar low-skilled ones; in FIRB, high-skilled white-collar jobs; and in community, social, and personal services (CSPS), jobs are evenly divided among high- and low-skilled white-collar jobs in most countries.

In terms of the dynamics of change, Graph 7 shows for six of the G7 countries a breakdown of employment growth in major services sectors by different types of occupations. It confirms that of all the services sectors, the FIRB sector shows the fastest growth in all six countries; in most cases, the occupational grouping mainly responsible for this growth is high-skilled white-collar workers (however, in 
the United States it is low-skilled white-collar). Second (although third in Japan) comes CSPS, with highand low-skilled white collar jobs contributing about evenly to the increase. In wholesale and retail trade, which follows in third place in most countries, the increase in low-skilled white-collar jobs (sales and service personnel) has generally contributed most to the overall job growth. The same is true in transport, storage, and communications services.

Is the upskilling indicated in the Graphs a widespread phenomenon occurring in every industry, or is it mainly due to employment shifts towards sectors that employ a majority of high-skilled workers? Berman et al. (1995) examined the change in shares of production workers and non-production workers in the manufacturing sector for a large set of countries and found that most upskilling occurs within industries and not as a result of employment shifts between industries. This result holds for developing as well as developed countries.

Using the methodology of Berman et al., Table 3 presents a breakdown of changes in high-skilled employment into that due to employment shifts between industries (the between-industry effect) and that due to changes in the occupational mix of industries (the within-industry effect). The occupational data cover seven countries, and the analysis differs from that in Berman et al. in two ways. First, it concerns services as well as manufacturing. Second, it uses a more precise definition of high-skilled workers, whereas Berman et al. examine the change in the share of non-production workers, a category that includes a large share of relatively low-skilled occupations. The table shows that within-industry changes account for most of the overall change in all of the seven countries except Italy, and that the rate of upskilling in the services sector often exceeds that in manufacturing. Goux and Maurin (1995) show that in France, a large portion of the upskilling occurs because there is a shift from the manufacturing to the services sector, but within manufacturing and services, upskilling occurs mainly within industries.

This analysis does not show that technology, or any other factor, is responsible for upskilling within industries; it simply shows that upskilling is occurring in most industries. However, these results have been used to make two arguments. First, if information technology is skill-biased and if information technology is used in almost every sector, then upskilling should occur within industries. Second, Berman et al. use these results to argue against the view that increased competition from low-wage countries is responsible for the decreased demand for low-skilled workers; they maintain that trade should induce employment shifts to relatively high-skill industries, and away from low-skill ones, rather than overall upskilling within each industry. This interpretation has been criticised, however, since trade and technological change both produce substitution and income effects, affecting the quantity of workers in an industry as well as its skill mix (Baldwin, 1995).

\section{Skills and technology}

Section 2 examined the evidence of the changing skills profiles in OECD economies, at both the aggregate level and a more disaggregated level, distinguishing between manufacturing and services and different industries within each of these.This section moves on to discuss the relationship between skills and technology. It starts off with a discussion of some of the conceptual issues involved, notably the concept of the "skill-bias" and the differences between analyses at the micro and the sectoral or macro level. It then briefly reviews the ongoing debate on the different possible causes of the decline in demand for unskilled workers, namely technology, trade and other factors relating to institutional characteristics and structural changes in OECD economies. It finally presents some empirical results on the relationship between various measures of technology and the process of upskilling based on industry-level regressions across a number of OECD countries. 


\section{Skills and technology: some conceptual issues}

When new technologies are introduced into production processes, it is generally thought that, overall, they reduce the demand for low-skilled workers and increase the demand for high-skilled workers. This complementarity between technology and high-skilled workers at the level of the firm can be explained by reference to three intuitive arguments. The first is that high-skilled workers adapt more easily to technological change than low-skilled workers. The second is based on the observation that many new technologies perform repetitive tasks traditionally carried out by low-skilled labour, or workers without extensive training, such as routine assembly operations. The third is that computer technologies increase the productivity of high-skilled workers more than low-skilled workers, so that firms match high-skilled workers with new technology. ${ }^{2}$

At the same time, and in addition to this "upskilling", technology can also have a "deskilling" effect, in the sense that it will lower the skills required for a certain task, so that as new technologies perform a greater variety of tasks, the skills required for certain occupations may be reduced. There is some early evidence that information technology is reducing middle-management jobs, traditionally thought of as skilled. With the development of "intelligent" software able to perform a variety of functions, information technology can now be used to perform many information gathering tasks and analyses in addition to simple computations.

The complementarity between technology and skills which is evident at the microeconomic level is often extrapolated to the level of the economy as a whole and is commonly referred to as "skill-biased technical change". From a theoretical point of view, however, micro-level complementarities between skills and technology do not necessarily translate into macro-level relationships. The overall impact will depend on substitution effects on both the factor and the product markets.

If technological change indeed acts as a shock to relative demand for skills and relative wages at the macro level, one should distinguish between the short and long run. Changes in relative prices and induced innovation can help to offset the shock. Rigidities in the labour market or lack of training can make the shock permanent. Empirically, there is evidence of increasing dispersion in relative wages over time in an number of countries; however, while the average wage has risen and been translated into welfare gains, there is also research pointing to the adverse effects that greater inequalities in income distribution may have on income growth. It is also difficult to separate the effects of technological change from a wide array of other forces and factors such as trade and institutional effects. During the 1980s, many countries underwent profound economic change, including increased liberalisation of product and labour markets. In addition, different countries have had different experiences in terms of changes in the supply of skilled and unskilled workers.

The most debated issue concerns the effects of trade. The basic argument is that trade with countries that are relatively rich in unskilled labour will reduce demand for low-skilled workers and increase demand for high-skilled workers at home. Thus, the effect of trade with low-skill, low-wage countries on domestic labour markets will be similar to that of skill-biased technological change. This argument has intuitive and popular appeal owing to the fact that trade with low-wage countries has increased markedly over the past two decades. In 1990, 12 per cent of imports into the EU countries came from non-OECD countries, whereas the figure was 35 per cent for the United States. In 1970, these figures were 5 and 12 per cent, respectively. More recently, greater attention has been focused on foreign direct investment in low-wage countries by multinational firms based in OECD countries. It is felt that the wages paid to low-skilled workers in OECD countries will be dictated by the wage rates in low-wage countries due to factor price equalisation ${ }^{3}$. 
Differences in labour market institutions have an impact on the equilibrating mechanisms of the labour market and influence which technologies are developed and adopted, and consequently, how they influence relative labour demand.Moreover, firms choose new process technologies in light of the skill levels of their work force and the relative costs of upgrading these skill levels. In countries with strong external labour markets, such as the United Kingdom and the United States, firms have more flexibility for adopting technology and seeking workers with the appropriate skills across the entire labour market. In countries that rely more on internal labour markets, such as France and Germany, where the costs of hiring and firing workers are greater, firms choose technology more on the basis of the skills and abilities of their workers and how easily they can adapt those skills to implement the new technology successfully.

Several authors have also examined factors such as changes in unionisation and collective bargaining, immigration, and changes in political regimes (Cotis et al., 1996). Some authors, for instance, have observed that the United States and the United Kingdom, two countries with fairly large increases in wage dispersion, underwent profound changes in tax and income policies in the 1980s. Partly because it is difficult to estimate the effects of such factors, no research has yet conclusively shown that the impact of these alternative explanations is large.

\section{Skills and technology: review of the evidence}

Empirical work on technology and skills has used both micro-level and industry data. The recent availability of large data sets at the level of individual establishments or firms in a number of OECD countries has provided a new powerful tool and given new insights into the relationships between technology and skills. ${ }^{4}$ The basic approach to estimating the effect of technological change on the demand for worker skills at the micro level is to use data sets containing information on technology and worker skills. Many countries have recently conducted special surveys on technology (such as the EU Innovation Survey and the US and Canadian surveys of manufacturing technology); these can sometimes be linked to data sets containing information on worker skills.

Studies that use firm-level or establishment-level data to investigate the relationship between technology and worker skills suggest that the development and use of advanced technologies is associated with the employment of highly skilled workers, although the direction of the causality is hard to establish. For the United States, Siegel (1995b), examining the relationship between computer expenditures and age and educational level, found a positive correlation between labour quality indices and computer expenditures. Nyholm (1995), using Danish data, found that establishments using advanced manufacturing technologies employ more highly skilled and educated workers than those that do not. Pacelli et al. (1995) show that the percentage of non-manual workers (white-collar) in Italy increases with technology for all firm sizes. Doms et al. (1995) examined the skill levels of workers in 358 US manufacturing establishments using information on the use of 17 advanced manufacturing technologies and found that the more technologically sophisticated establishments employed more highly educated workers, more scientists and engineers, and more production workers with at least some university training.

As with many aspects of the issue of technology and worker skills, an important constraint in these studies has been the lack of the time series data needed to evaluate the questions of causality. While a number of countries have conducted special surveys on technology, most of these surveys only involve crosssections. Several countries are now developing panel data sets with information on technology and worker skills. Nonetheless, various recent studies have shed light on this issue and have been able to establish a causal relation between technology and worker skills.

Among such studies, Doms et al. (1995) found that US establishments that adopted advanced technologies by 1993 had relatively high-skilled work forces in 1977. Siegel (1995) examined longitudinal data on a set 
of US manufacturing plants and found a positive relationship between technology use and worker skills, but also support for upgrading of skills once new technology was installed. Baldwin et al. (1995) used several Canadian surveys to obtain much more direct evidence on whether technology requires more skilled workers. They found that, depending on the technology, skill requirements increased in between 47 and 59 per cent of firms adopting new technologies, while only a negligible number of firms reported reduced skill requirements. In conclusion, there is evidence both that higher skills are needed to implement technology successfully and that implementing technology will raise the skill level required of the work force.

The studies using these data examine the correlation between various measures of technology and worker skills and wages. While providing important new insights, they also have some shortcomings. Owing largely to the availability of data, a disproportionate number of these have focused on technology and skills in manufacturing rather than services industries. Furthermore, many of these studies are not internationally comparable and are unable to draw conclusions about reasons for changes in the aggregate demand for skills. Furthermore, while micro-level studies offer important insights as to how technology affects wages and the demand for workers with different skills, by their nature, they cannot lead to generalisations about aggregate effects at the level of industries or of the economy as a whole. Aggregatelevel evidence, on the other hand, is difficult to come by because of a lack of data sets with information on both technology and worker skills.

Using industry-level data, Berndt et al. (1992) examined the relationship between worker skills and hightechnology capital intensity for US manufacturing industries; they found a positive correlation between high-technology capital intensity and white-collar workers. They also noted a significant increase in educational level among blue-collar workers. Berman et al. (1994) examined the evolution of skills for US manufacturing industries and the wage share of white-collar and blue-collar workers. They found that skill upgrading (increase in the wage share of white-collar workers) is positively related to two measures of technology: computer expenditures and research and development. Using two-digit manufacturing data, Bartel and Lichtenberg (1987) found that the age of the capital stock (a proxy for technology) is inversely related to the percentage of labour costs for highly educated workers; this indicates that industries with high-skilled workers may be more adept at adopting new technologies. Machin (1996), using annual twodigit manufacturing industries data for the UK in the 80s, finds positive correlations between changes in non-manual employment and wage shares and technology related variables such as R\&D intensity, innovation counts and a measure of establishment-level computer usage.

The econometric specification used in these studies is typically derived from a variable cost function with capital as a fixed factor input. Assuming a translog functional form the estimated equation in first differences is:

$$
\Delta \text { Share }_{\mathrm{i}, \mathrm{t}}=\alpha_{0}+\alpha_{2} \Delta \log \mathrm{W}_{\mathrm{i}, \mathrm{t}}+\alpha_{3} \Delta \log \mathrm{K}_{\mathrm{i}, \mathrm{t}}+\alpha_{4} \Delta \log \mathrm{Y}_{\mathrm{i}, \mathrm{t}}
$$

where Share is either the share of non-manual wages in total wages or the share of non-manual employment on total employment, $\mathrm{W}$ is the vector of relative wages of non manual and manual workers, $\mathrm{K}$ is the capital stock and Y is output. In the estimation the vector of relative wages is usually dropped on the grounds of endogeneity bias. Finally to assess the impact of technological change on the trend in the share, various indicators $(T E C H)$ are simply added to the regressors:

$$
\Delta \text { Share }_{i, t}=\alpha_{0}+\alpha_{2} \Delta \log \mathrm{K}_{\mathrm{i}, \mathrm{t}}+\alpha_{3} \Delta \log \mathrm{Y}_{\mathrm{i}, \mathrm{t}}+\alpha_{4} \mathrm{TECH}_{\mathrm{i}, \mathrm{t}}+\mathrm{u}_{\mathrm{i}, \mathrm{t}}
$$

\section{Upskilling and technology: sectoral evidence across OECD countries}


The existing empirical literature at sectoral and micro level provides evidence for individual countries' experiences. In this study we try, instead, to draw some more general conclusions regarding technology and the use of skills by looking across sectors and by exploiting a new data set which allows cross-country comparisons. $^{5}$

We do observe a sort of persistance in the data at hand. The sectors which were investing more in $R \& D$ at the beginning of the 80s continued to do so ${ }^{6}$ at the beginning of the 90s (Graph 8). The sectors which had an higher share of high skilled people at the beginning of the period have been employing them at an increasing rate (Graph 9). To test this endogenously determined process we would need a more appropriate framework. We can nevertheless carry out empirical exercises which point to the importance of innovation and investment in innovative activities in the accumulation of human capital.

Given that most of the upskilling takes place within sectors and that in each sector we might observe some persistent employment dynamics we test the hypothesis that the change in the skill composition in each manufacturing industry will follow the general upskilling trend in manufacturing with some deviations from it. The approach tries to capture the technology-related elements that would characterise the relative position of each sector with respect to the average trend. Using a cross-section of 22 manufacturing sectors in five of the G7 countries, we regress the annual change in the share of white-collar high-skilled workers $(\triangle S H)$ on R\&D intensity at the beginning of the period $R D I$ (defined as R\&D expenditure per unit of gross output), initial capital-to-labour ratio (IKI), the change in relative $\mathrm{R} \& \mathrm{D}$ intensity or the growth rate in number of patents $(G R P)$. All variables are expressed as deviations from the manufacturing average.

$$
\Delta \mathrm{SH}_{\mathrm{i}, \mathrm{T}}=\alpha_{0}+\alpha_{1} \mathrm{RDI}_{\mathrm{i}, 0}+\alpha_{2} \mathrm{IKI}_{\mathrm{i}, 0}+\alpha_{3} \mathrm{GRP}_{\mathrm{i}, \mathrm{T}}
$$

The initial capital-to-labour ratio (IKI) controls for some technology characteristics of production or complementarities relations generally observed at the micro level between skilled labour and physical capital. R\&D intensity at the beginning of the period $(R D I)$ should capture sectoral differences in past investment in human capital input. It reflects the number of researchers at that point in time, since R\&D expenditure is mainly constituted by researchers' salaries. Under assumptions of proportionality between changes in R\&D flows and R\&D stock, the relative change in R\&D intensity should pick up the effect of relatively higher investment rates in technology by a given industry. Another measure of the relative innovation effort in each sector is given by growth rates in the number of patents $(G R P)$ by sector. Table 4 presents the results.

Overall the increase in the share of white-collar high-skilled workers within sectors is positively correlated to variables related to technological change, such as $R \& D$ investment and growth in the number of patents; this is especially true in the high-technology sectors. The RDI coefficient is robust to changes in the country sample, and a one percentage point $R \& D$ intensity higher than average at the beginning of the eighties has implied about a twenty per cent higher than average upskilling per year. The coefficient is strongly sensitive to variations in the sectors; letting the coefficient vary across sectors gives estimates that range from 0.63 for high technology (HT) sectors to 0.2 for medium technology (MT) and 0.15 for low technology (LT). The results confirm a strong positive correlation between the increasing share in whitecollar high-skilled workers and initial R\&D intensity (see Graph 8). Changes in relative R\&D intensities or growth rates in the number of patents, are significant also but have very little impact. The relative initial capital-labour ratio is less robust if one controls for outliers or if the sample is changed.

If one considers individually the other three broad skill categories (white collar low-skilled, blue -collar high-skilled and blue-collar low-skilled), the picture becomes blurred and the "technology" variables do not seem to capture their relative sectoral dynamics. Interestingly, the behaviour of the white-collar lowskilled category is closer to the blue-collar low-skilled category. In both cases, changes in the shares seem 
to have a negative correlation with initial $R \& D$, but the other variables are not significant. In the bluecollar high-skilled regression even the impact of relative initial $R \& D$ is not significant.

In conclusion the sectors that invested more in research and performed more innovative activity are those that employed a larger share of higher skilled people at the beginning of the 1980s and that continued to accumulate human capital during the decade. We suggest that the increased upskilling is not merely a consequence of some labour-biased technological shock. Human capital accumulation and innovative effort can be read as a joint process which renforces in a cumulative way and can create some phenomenon of persistence in industrial performance.

This could be particularly true for those innovation activities carried out by firms to mantain their market share. In a dynamic setting, in which firms have to continuosly improve the quality of their product to be competitive, differences in incentives to innovate might affect the distribution of successful firms over time. In D. Ulph's words (1996) it might turn out that firms that become successful are on average more likely to be successful in the future, this giving raise to equilibria characterised by an high degree of persistence. The key to success could be the availability of a skilled labour force, easily adaptable to innovations. The cost to innovate for those firms that have an higher availability of the right skills will be lower, they will invest more in innovation, they will have higher profits and will be able to attract more human capital. We are going to exploit this last assumption in the following analysis.

\section{The accumulation of human capital and the role of technology investment and diffusion}

The estimation of (3) has allowed to establish some correlations between changes in the relative demand for skilled labour and technology related variables. A more structured approach is followed here in order to have a closer look at the determinants of the demand of skilled labour. Firstly, this approach allows to focus on the growth of an occupational category which presupposes a certain degree of education. Secondly, a common criticism is that $R \& D$ is not a good measure of technology. The novelty here is to consider R\&D not as a measure of technical change but as an investment in inputs devoted to perform some innovative activity. This also allows us to look at direct investment as well as investment through purchase of imported inputs.

The framework adopted is that of a sectoral demand for an input. Demand for a factor $i$ in sector $s$ can be disaggregated in the unit demand for the factor which is a function of the cost vector, the demand for the product produced in the sector and technology related factors which favour the use of the factor (in the hypotheses that technological progress which enhances the productive use of all factors would be reflected in higher value added growth):

$$
\mathrm{L}_{\mathrm{i}, \mathrm{S}, \mathrm{T}}=\mathrm{T}_{\mathrm{i}, \mathrm{S}, \mathrm{T}} * \mathrm{Y}_{\mathrm{S}, \mathrm{T}} * \mathrm{x}_{\mathrm{i}, \mathrm{S}, \mathrm{T}}\left(\mathrm{w}_{\mathrm{i}, \mathrm{S}, \mathrm{T}}, \xi_{\mathrm{S}, \mathrm{T}}\right)
$$

where:

$L_{i, S, T}=$ number of i-type of workers employed in sector s

$T_{S, T}=$ technology in sector s which favours the use of the input $\mathrm{i}$

$Y_{S, T}=$ demand for the goods produced in sector $\mathrm{s}$

$x_{i, S, T}=$ unit demand for i-type of workers derived from the cost function

$w=$ vector of relative factor prices in sector $\mathrm{s}$ 
$\xi_{s, T}=$ some input complementary to the use of workers of the i-type (eg. to perform innovation activities one needs to provide workers with research facilities)

By the principle of duality in production the cost function of a firm summarizes all of the economically relevant information about technology ${ }^{7}$. Cost minimization implies that the optimal cost function is a function of conditional factor demands. Hence in the empirical estimation we proxy unit demand with the unit cost sustained to acquire the input. This cost is assumed to have two components: skilled labour compensation and the cost sustained for inputs complementary to the use of skilled labour. The assumption tested here is that costs are decreasing in the stock of the complementary inputs to the demanded factor. A greater stock of R\&D resources in the sector makes the employment of higher skilled people less costly than on average, or otherwise said, it makes workers more efficient. In terms of growth rates and proxying unit demand with unit cost and demand for the product with value added (VA) the estimated equation is:

$$
\Delta \log \mathrm{H}_{\mathrm{S}, \mathrm{T}}=\alpha_{0}+\alpha_{1} \Delta \log \mathrm{VA}_{\mathrm{S}, \mathrm{T}}+\alpha_{2} \Delta \log \mathrm{P}_{\mathrm{S}, \mathrm{T}}+\alpha_{3} \log \mathrm{RDI}_{\mathrm{S}, \mathrm{T}}+\alpha_{4} \Delta \log \mathrm{LPTY}_{\mathrm{S}, \mathrm{T}}
$$

where $\mathrm{H}$ is the number of high skilled workers, $V A$ is the sectoral value added, and $P$ is the number of patents granted and proxies the sectoral technological progress. The last two variables represent the change in the cost function driven by changes in relative factor prices (proxied by the growth in total labour productivity) and changes in the total stock of resources devoted to research (direct and embodied R\&D expenditure as a share of production). Table 5 presents the impact of total investment in R\&D resources (direct or through imports) on the accumulation of skilled workers:

$R \& D$ investment plays a relevant role in the sectoral employment of human capital ${ }^{8}$. Moreover the relevant channels through which $R \& D$ flows have an impact on the accumulation of human capital, direct or indirect through technology diffusion, can differ across sectors. We find that in the high technology sectors, which by definition are characterised by an higher level of $R \& D$ expenditure, direct $R \& D$ plays a major role. The low technology sectors, though, greatly benefit from R\&D spillovers coming from imports. Regressions at a more disaggregated occupational level within the high skilled workers show that the above trends are confirmed for the first and third category (managers and technicians) while the growth rate of second category (mainly professionals and scientists) is mainly correlated with the innovation rate proxied by the number of patents.

\section{Concluding remarks}

The paper set out to highlight stylised facts about recent trends in the skill distribution of employment and to analyse the role that technological change might have in explaining these dynamics. Data on industrial employment broken down by occupation recently assembled by the OECD Secretariat were used in order to examine the changing skill composition of OECD economies, the occupational structure of industry and services industries, and the dynamics of upskilling.

These data suggest that in most OECD countries during the 1980s, employment grew fastest in highskilled jobs and slowest - or declined - in low-skilled jobs. Within the white collar group of occupations, high-skilled jobs have tended to show the fastest growth. Within the blue-collar group of workers, highskilled jobs have declined in most countries, while blue-collar low-skilled ones show a more diverse picture by country. Despite these trends, the majority of occupations remain low-skilled (accounting for between two-thirds and three-quarters of the total, depending on the country), but the share of high-skilled occupations is steadily rising in all countries. 
Underlying the overall upskilling trend which can be observed in OECD countries at the level of total employment is a contrasting evolution in manufacturing and in the services. It is in manufacturing where the upskilling trend is most apparent: while overall manufacturing employment has declined in most countries, white collar high-skilled manufacturing jobs have continued to increase, while blue-collar lowskilled ones have shown the steepest decline. In contrast, in the services, where overall employment growth has been robust, white collar low-skilled jobs have increased almost as fast as white collar highskilled ones, with blue-collar high-skilled jobs showing the weakest growth.

Overall, most of the shift away from unskilled and towards skilled employment reflects a true upskilling process rather than a change in the industrial composition of economies: shifts have occurred primarily within industries, rather than between them. This is true both in manufacturing and in the services, but particularly in manufacturing.

The role of technology in explaining upskilling trends was examined with the help of cross-sectoral regressions for 22 manufacturing industrial sectors in five of the G7 countries in the 1980s. The impact of R\&D flows on the employment of high skilled workers was examined through different channels, and a distinction was made between direct $R \& D$ expenditure and $R \& D$ diffusion through foreign spillovers.

The focus of the analysis was not on assessing the relative impact of technology vis-a-vis other factors on changes in the skill mix, a question which needs to be addressed with an appropriate framework in which technology, trade, institutional and other factors interact together and in which appropriate measures of technological change are available. Instead, and in contrast with other studies, an attempt was made to explain general trends in the skill mix with correlations which are valid across countries by combining new internationally comparable data on skills with data on R\&D investment and diffusion at the sectoral level.

The results showed a correlation between the relative position of each manufacturing sector with respect to the average upskilling trend and technology-related variables such as expenditure in R\&D and growth rates in the number of patents. Moreover, human capital was shown to have accumulated faster in those sectors which were more intensive in the use of high skilled workers at the beginning of the 1980s. Human capital accumulation and innovative efforts can be read as a joint process which renforces in a cumulative way and can create some phenomena of persistence in industrial performance.

The paper also presented some preliminary results concerning the impact of technology investment and diffusion on the growth rate of employment of high skilled workers. The impact of R\&D flows on the accumulation of human capital was examined through different channels, and a distinction was made between direct $R \& D$ expenditure and $R \& D$ diffusion through domestic and foreign spillovers.

The results point especially to the role that R\&D investment plays in the accumulation of certain skills. In particular they suggest that is necessary to go beyond the capital-skill complementarity observed at the micro level and the use of $R \& D$ as a proxy of technical change as it is in sectoral empirical studies. R\&D is investment in human capital and past investments might affect the cost and incentives to employ human capital in the future. 


\section{NOTES}

1. International comparability of skill levels based on occupations is achieved by reclassifying national data into the ISCO-88 classification of occupations of the International Labour Office. Nevertheless different national practices in reclassifying national figures into the ISCO format may limit strict comparabiity. In the case of Germany for example, lower figures for white collar high skilled workers are partly due to the large share of workers classified as high-skilled blue-collar. Internationally comparable occupational data series for the United Kingdom are not available.

2. The complementarity between technology and skills has been recognised for some time. Using capital accumulation as an indirect measure of technology, Griliches (1969) argued "that educated labour is complementary to, rather than a substitute for, various advanced forms of machinery and that therefore a rapid rate of capital accumulation (and innovation) will increase the demand for such labour and prevent the fall in its relative price". These views are consistent with many labour demand studies, from a wide variety of countries, that find capital and skilled workers to be complementary (see the review by Hamermesh, 1994).

3. See for example Freeman 1995, "Are Your Wages Set in Beijing?" .

4. The results from many of these studies were presented in a Conference on "The Effects of Technology and Innovation on Firm Performance and Employment", organised jointly by the OECD, the US National Academy of Sciences and Industry Canada and held in Washington, DC, on 1-2 May 1995.

5. Another study using comparable data for four countries (US, UK, Sweden, Denmark) is: S. Machin, A. Ryan, J. Van Reenen, "Technology and Changes in Skill Structure: Evidence from an International Panel of Industries" presented at the Conference on Technology, Employment and Labour Markets, held in Athens, May 16-18 1996. They pool manufacturing sectors and time series for each of the four countries and find a positive and significant correlation between the within-component of changes in both the wage bill and employment shares and lagged R\&D (used as a comparable measure of technological change).

6. Exceptions are given by some US high-technology sectors for which R\&D expenditure and intensity have been declining in the 80s.

7. See Hal R. Varian, "Microeconomics Analysis, 1992, W.W. Northon \& Company.

8. Machin, A. Ryan and J. Van Reenen (1996) also find a positive correlation between growth in non-production workers and lagged R\&D intensity for three of the four countries (see footnote above). 


\section{REFERENCES}

BALDWIN, J., T. GRAY and J. JOHNSON (1995), "Technology Use, Training, and Plant-Specific Knowledge in Manufacturing Establishments", Research Paper Series No. 92, Analytical Studies Branch, Statistics Canada.

BALDWIN, R.E. (1995), "The Effects of Trade and Foreign Direct Investment on Employment and Relative Wages", OECD Economic Studies, No. 23, Winter.

BARTEL, A. and F. LICHTENBERG (1987), "The Comparative Advantage of Educated Workers in Implementing New Technology", The Review of Economics and Statistics, Vol. 69, February, pp. $1-11$.

BERMAN, E., J. BOUND, and Z. GRILICHES (1994), "Changes in the Demand for Skilled Labor Within U.S. Manufacturing: Evidence from the Annual Survey of Manufacturers", Quarterly Journal of Economics, June, pp. 367-397.

BERNDT, E., C. MORRISON, and L. ROSENBLUM (1992), "High-Tech Capital Formation and Labor Composition in U.S. Manufacturing Industries: An Exploratory Analysis," NBER Working Paper 4010, Cambridge, MA.

COTIS, J.-P., J.-M. GERMAIN, and A. QUINET (1996), “Technical Progress, International Trade, and Low-Skilled Labour", STI Review No. 18, OECD, Paris.

DAVIS, S. (1992), "Cross-country Patterns of Change in Relative Wages", NBER Working Paper 4085, Cambridge, MA.

DOMS, M., T. DUNNE, and K. TROSKE (1995), "Workers, Wages, and Technology", paper presented at the conference on "The Effects of Technology and Innovation on Firm Performance and Employment", Washington, DC, 1-2 May.

FREEMAN, R. (1995), “Are Your Wages Set in Beijing?", Journal of Economic Perspectives, Vol. 9(3), Summer, pp. 15-32.

GLYN, A. (1995), "The Assessment: Unemployment and Inequality", Oxford Review of Economic Policy, Vol. 11(1), pp. 1-25.

GOUX, D. and E. MAURIN (1996), "Changes in the Demand for Skilled Labour in France", STI Review No. 18 , OECD, Paris.

KATZ, L., G. LOVEMAN, and D. BLANCHFLOWER (1993), "A Comparison of Changes in the Structure of Wages in Four Countries", NBER Working Paper No. 4297, Cambridge, MA.

MACHIN, S., A. RYAN and J. VAN REENEN (1886), "Technology and Changes in Skill Structure: Evidence from an International Panel of Industries" presented at the Conference on Technology, Employment and Labour Markets, held in Athens, May 16-18 1996.

NICKELL, S. and B. BELL (1995), "The Collapse in the Demand for the Unskilled and Unemployment across the OECD", Oxford Review of Economic Policy, Vol. 11(1), pp. 40-62.

NYHOLM, J. (1995), "Information Technology, Productivity and Employment in the Danish Manufacturing Sector", paper presented at the conference on "The Effects of Technology and Innovation on Firm Performance and Employment", Washington, DC, 1-2 May.

OECD (1996), Technology, Productivity and Job Creation, Paris.

SIEGEL, D. (1995), "The Impact of Computers on Manufacturing Productivity Growth: A Multipleindicators, Multiple-causes Approach", The Review of Economics and Statistics (forthcoming).

PACELLI, L., F. RAPITI, and R. REVELLI (1995), "Intensity of Innovation, Employment and Mobility of Workers in Italy: Evidence from a Panel of Workers and Firms", paper presented at the conference on "The Effects of Technology and Innovation on Firm Performance and Employment", Washington, DC, 1-2 May. 
ULPH, D., 1996, Dynamic Competition for Market Share and the Failure of the Market for Skilled Labour, in A.L. Booth and D.J. Snower (eds), Acquiring Skills. Market Failures, Their Symptoms and Policy Responses, Center for Economic Policy Research, pp. 89-108.

WOLFF, E. (1996), "Technology and the Demand for Skills", STI Review No.18, OECD, Paris. 
Graph 1. Employment growth for blue- and white-collar workers over the 1980s Average annual growth rate

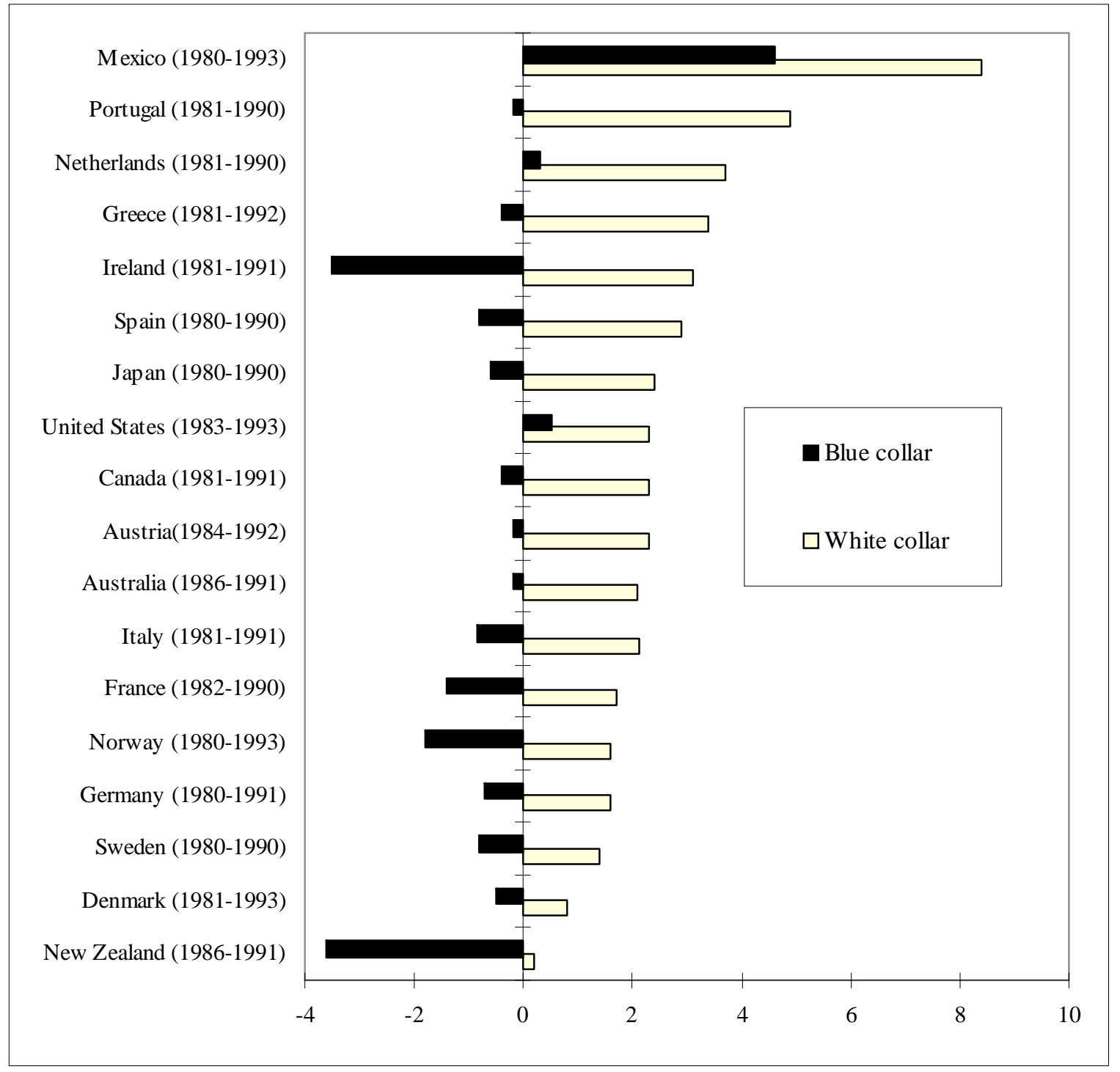

Source: OECD Secretariat calculations from International Labour Office data. 
Graph 2. Employment growth by skill group ${ }^{1}$

Average annual growth rates betwen indicated years

United States 1983-1993

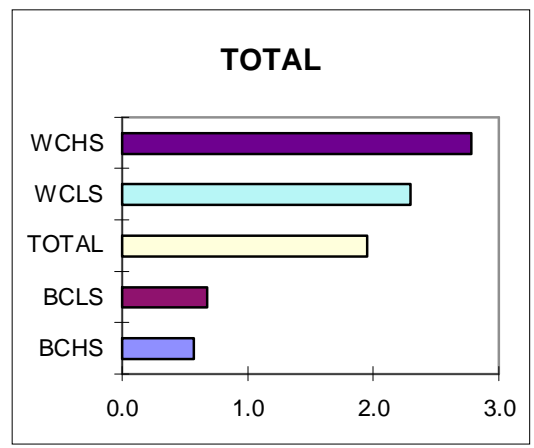

\section{Japan 1980-1990}

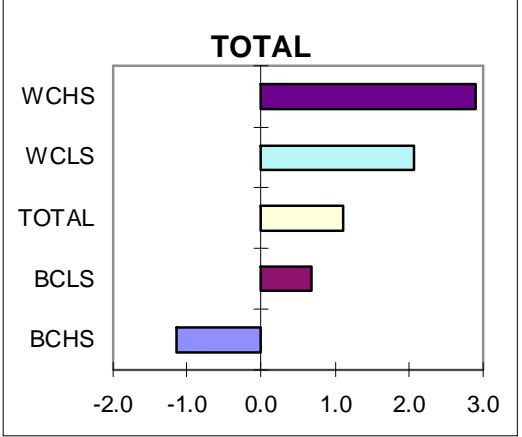

\section{France 1982-1990}

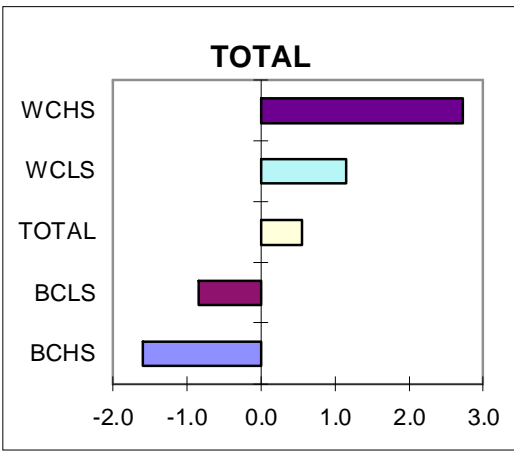

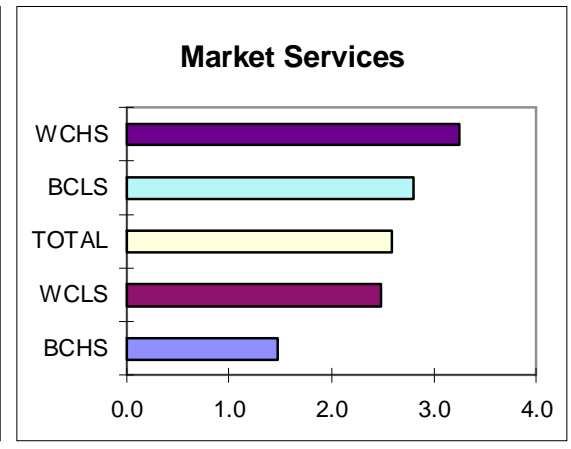
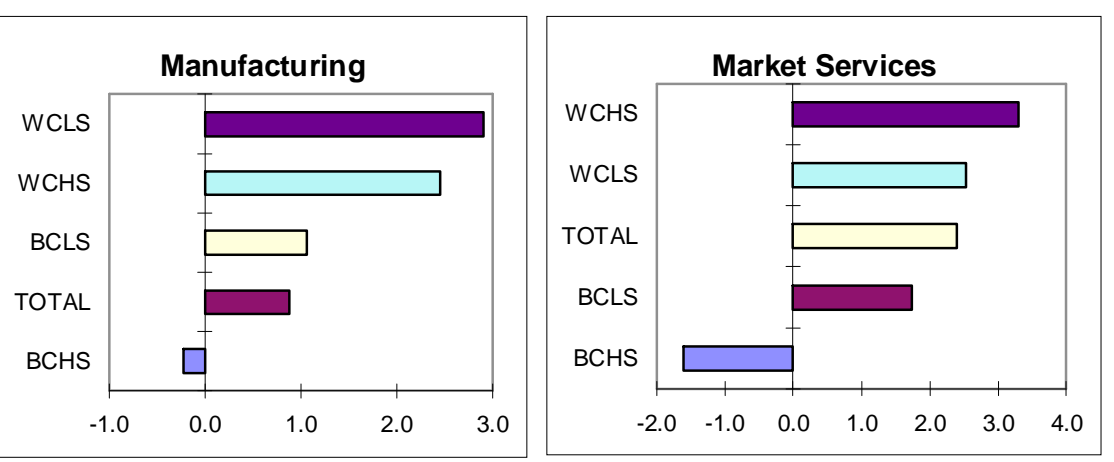

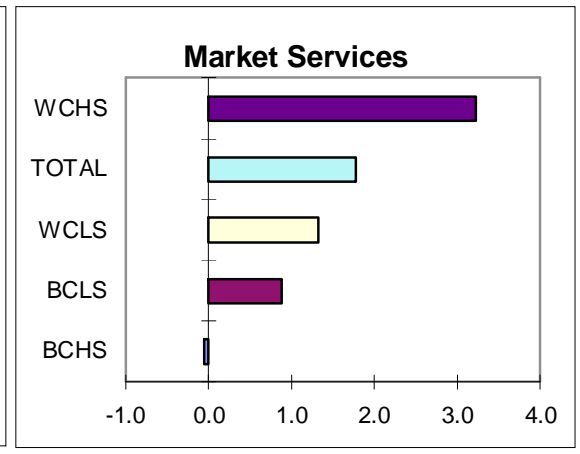

Germany 1980-1990
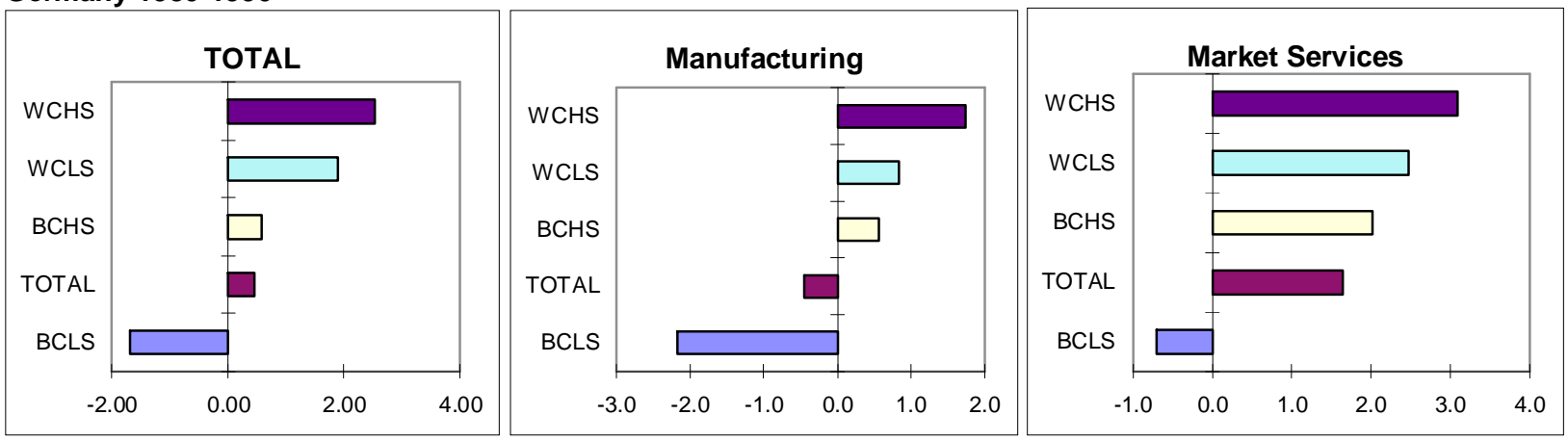

1. WCHS: white-collar high-skilled; WCLS: white-collar low-skilled; BCHS: blue-collar high-skilled; BCLS: blue-colar lowskilled. 
Graph 2 (cont). Employment growth by skill group ${ }^{1}$

Average annual growth rates betwen indicated years

Italy 1981-1991
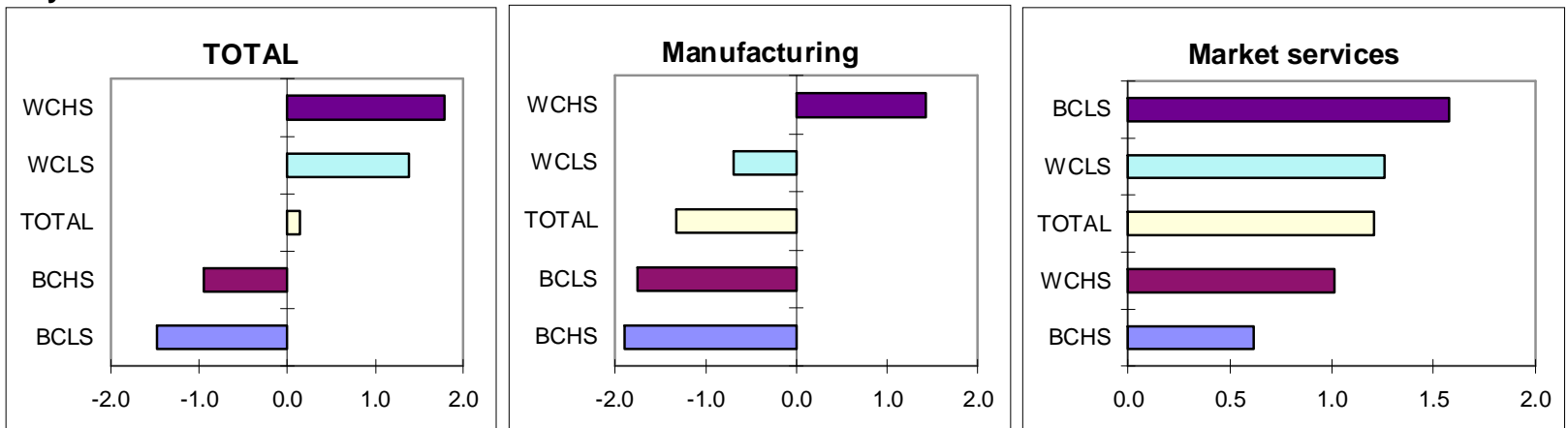

\section{Canada 1981-1991}
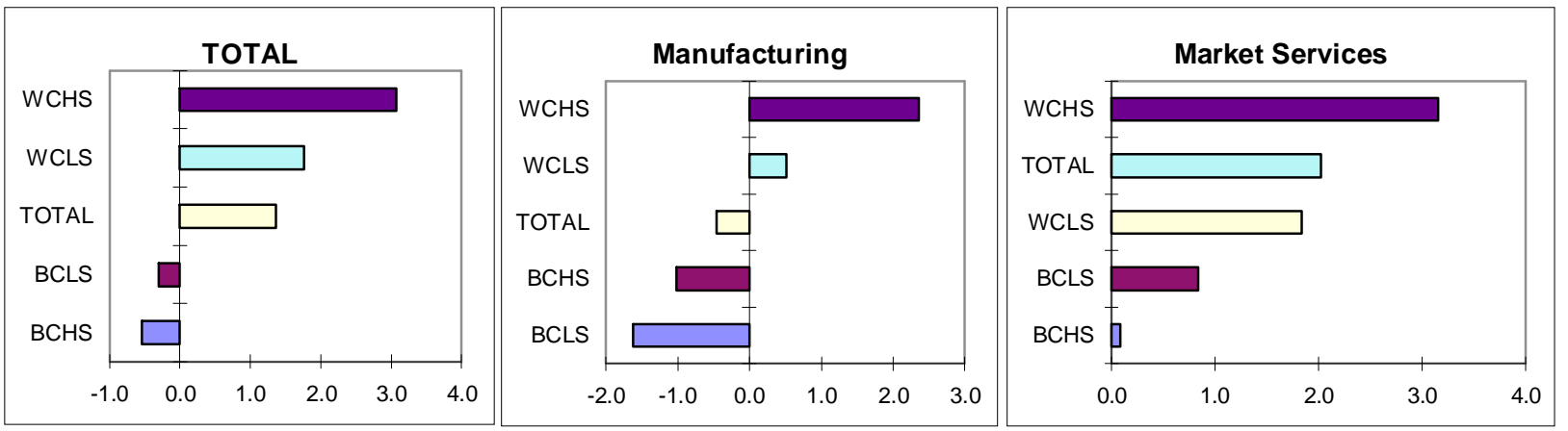

Australia 1986-1991
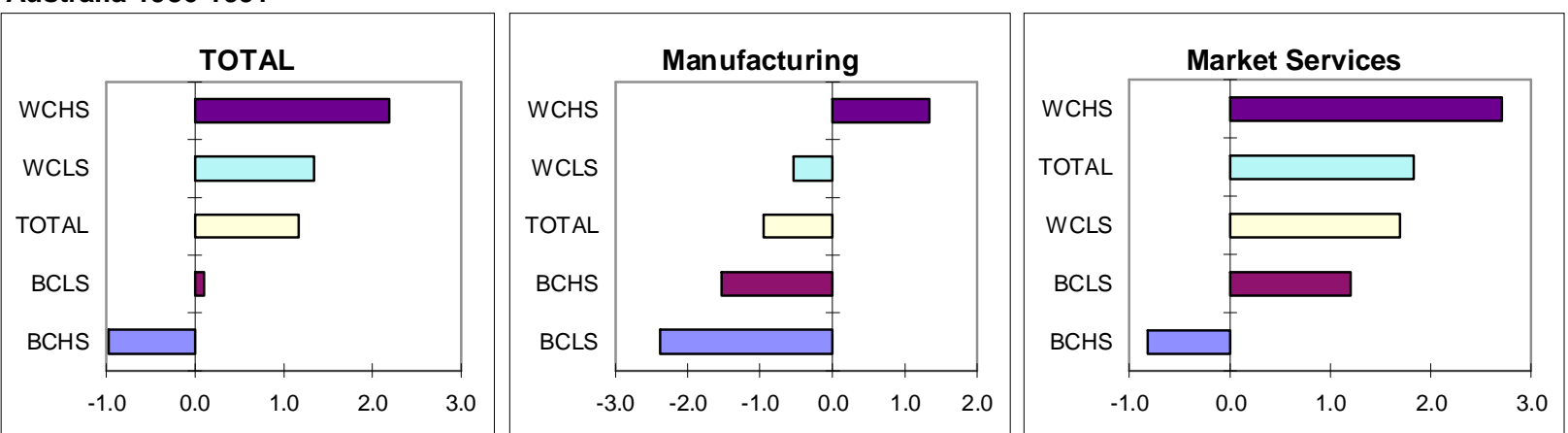

\section{New-Zealand 1986-1991}
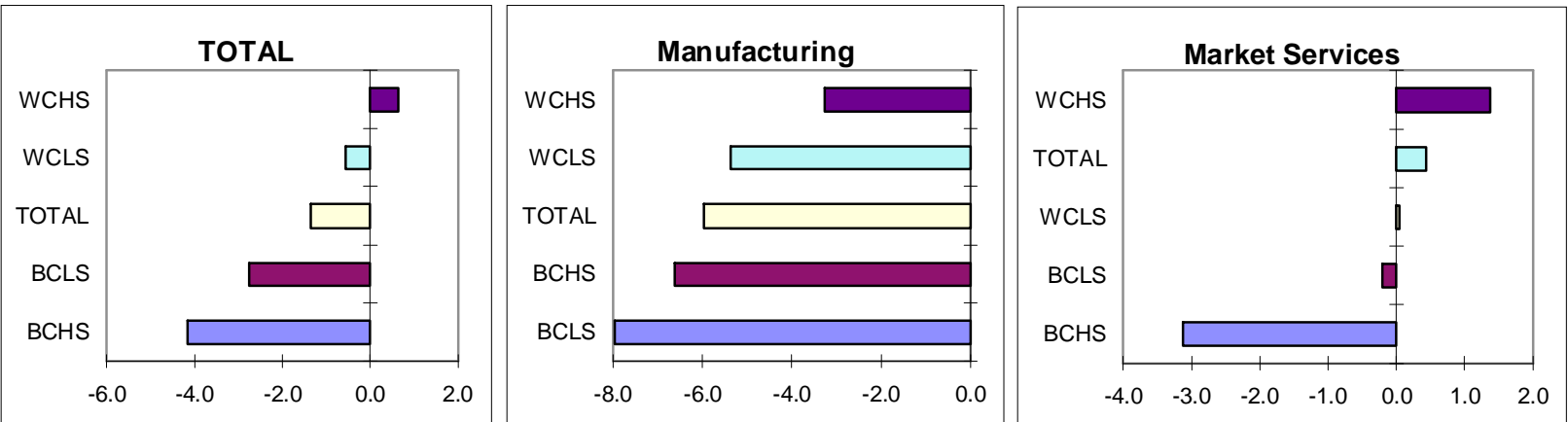

1. WCHS: white-collar high-skilled; WCLS: white-collar low-skilled; BCHS: blue-collar high-skilled; BCLS: blue-colar lowskilled.

Source: OECD, DSTI/EAS Division. 


\section{Graph 3. Employment growth of high skilled and low-skilled workers ${ }^{1}$}

Average annual growth rates

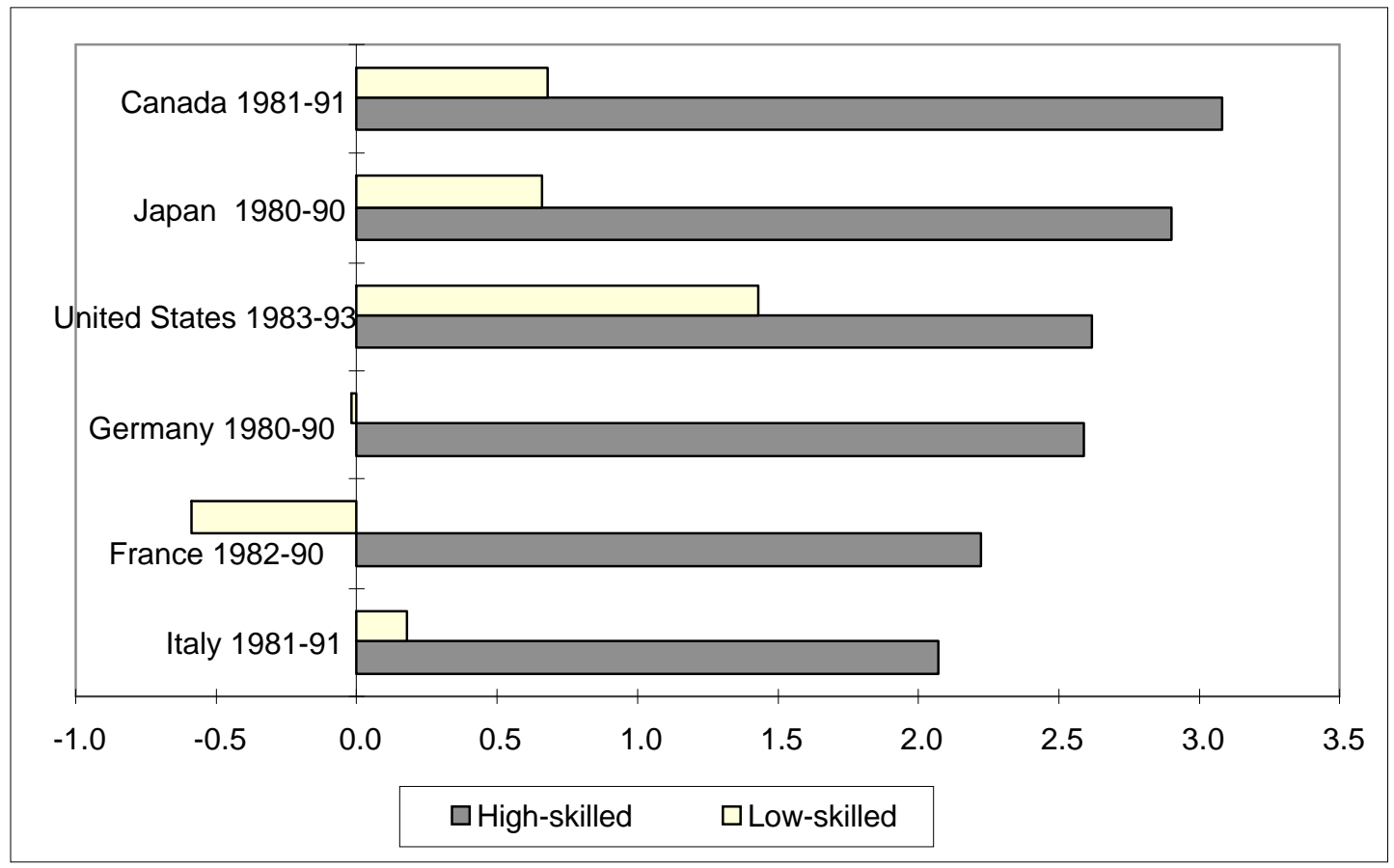

1. "High skilled" workers are defined here as those in the following occupational groups: Legislators, senior official and managers (ISCO-88 Group 1); professionals (ISCO-88 Group 2); technicians and associate professionals (ISCO-88 Group 3). All remaining occupational groups are classified as "low-skilled". For Germany, ISCO-88 Group 1 covers legislators and senior officials only and ISCO-88 Group 3 excludes Teaching associate professionals so that highskilled workers are underestimated.

Source: OECD Secretariat estimations from national data (STI/EAS Division). 
Graph 4. Skill composition

Ratio of White collar High skilled / White collar Low skilled

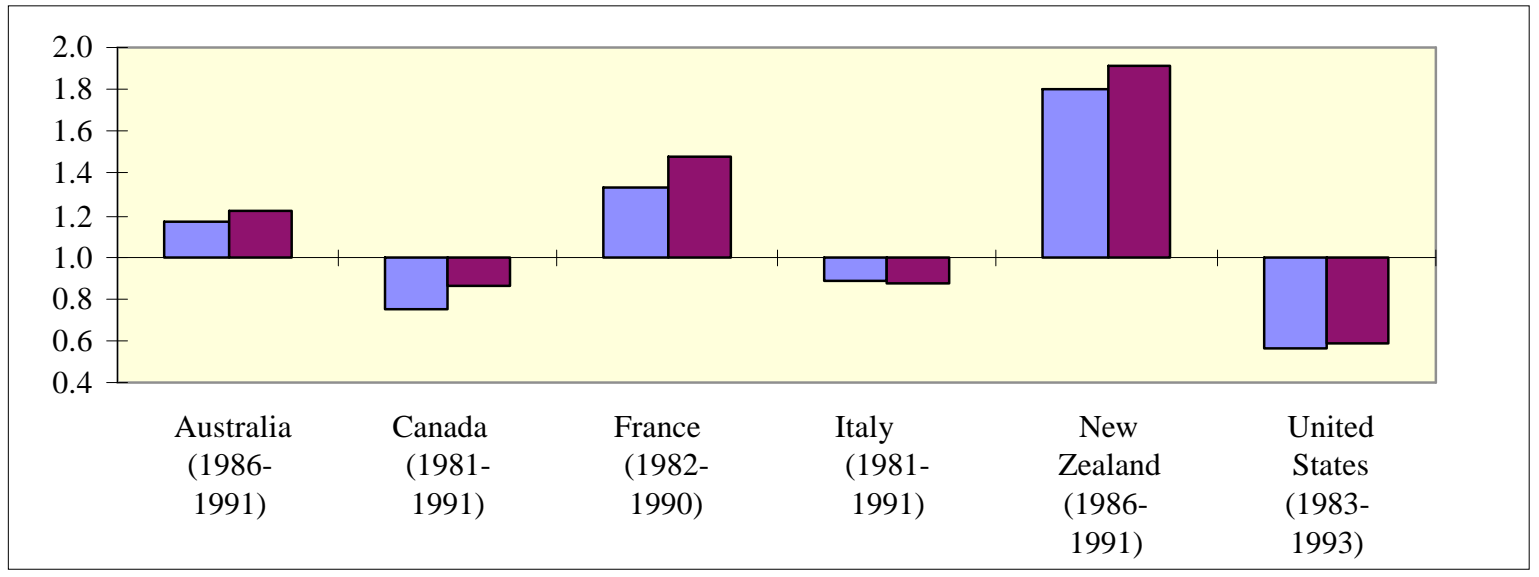

Ratio of Blue collar High skilled / Blue collar Low skilled

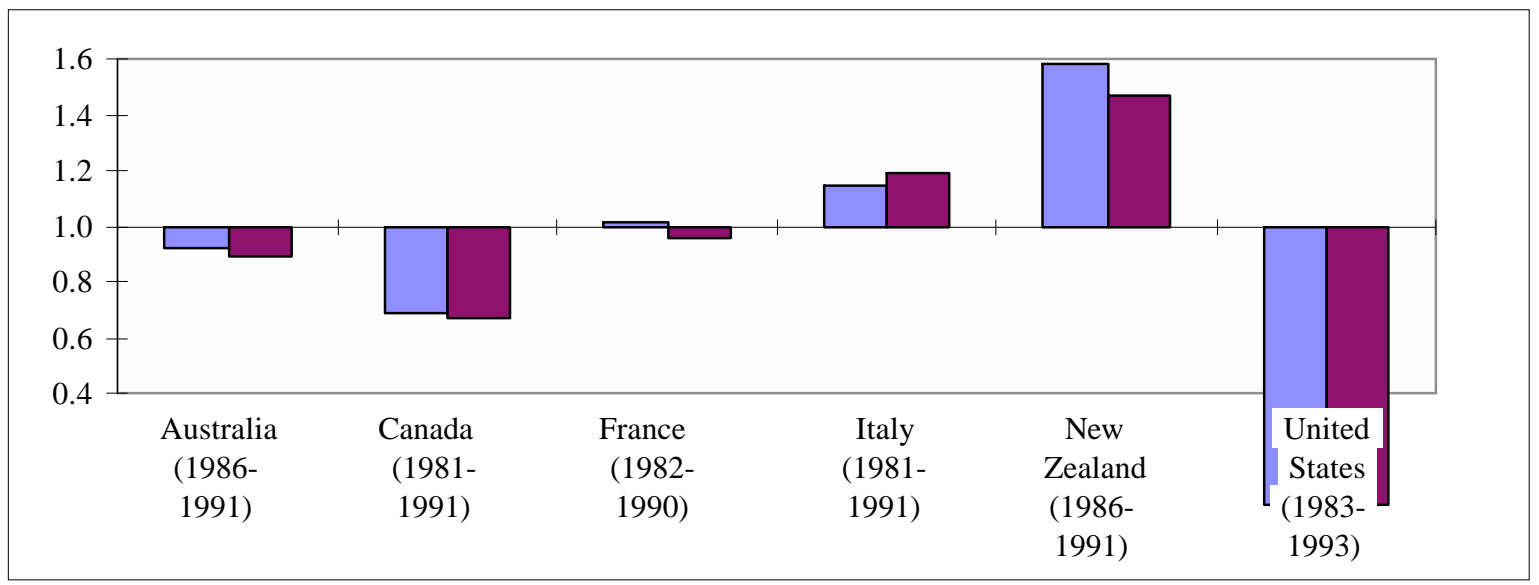

Ratio of White collar High skilled / Blue collar Low skilled

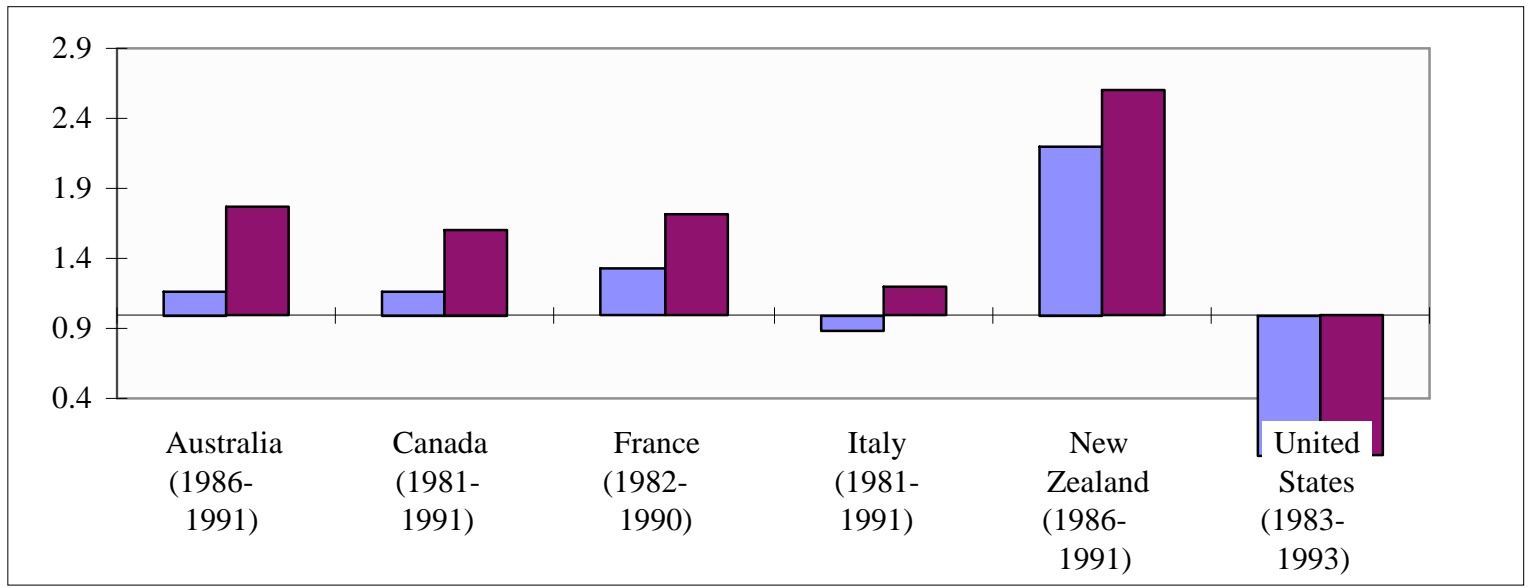

Source:OECD (DSTI/EAS Division). 
Graph 5. Employment growth breakdown by skill level in manufacturing and services

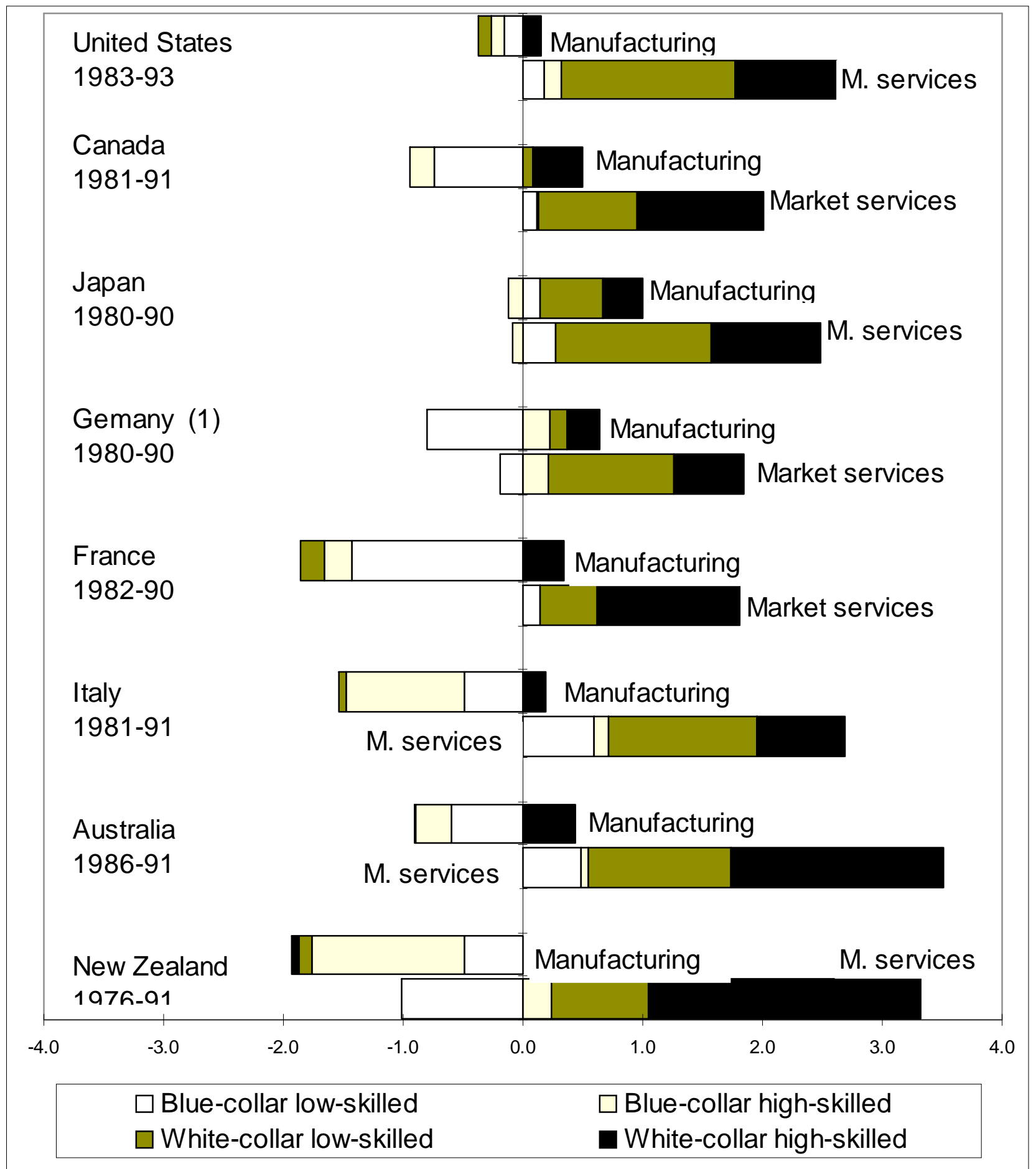

Note: See text for definitions.

1. The white-collar high-skilled group in Germany excludes some occupations and is thus underestimated. Source: OECD Secretariat calculations from national data; STI/EAS Division. 
Graph 6. Breakdown of manufactuting employment growth by skills and levels of technology

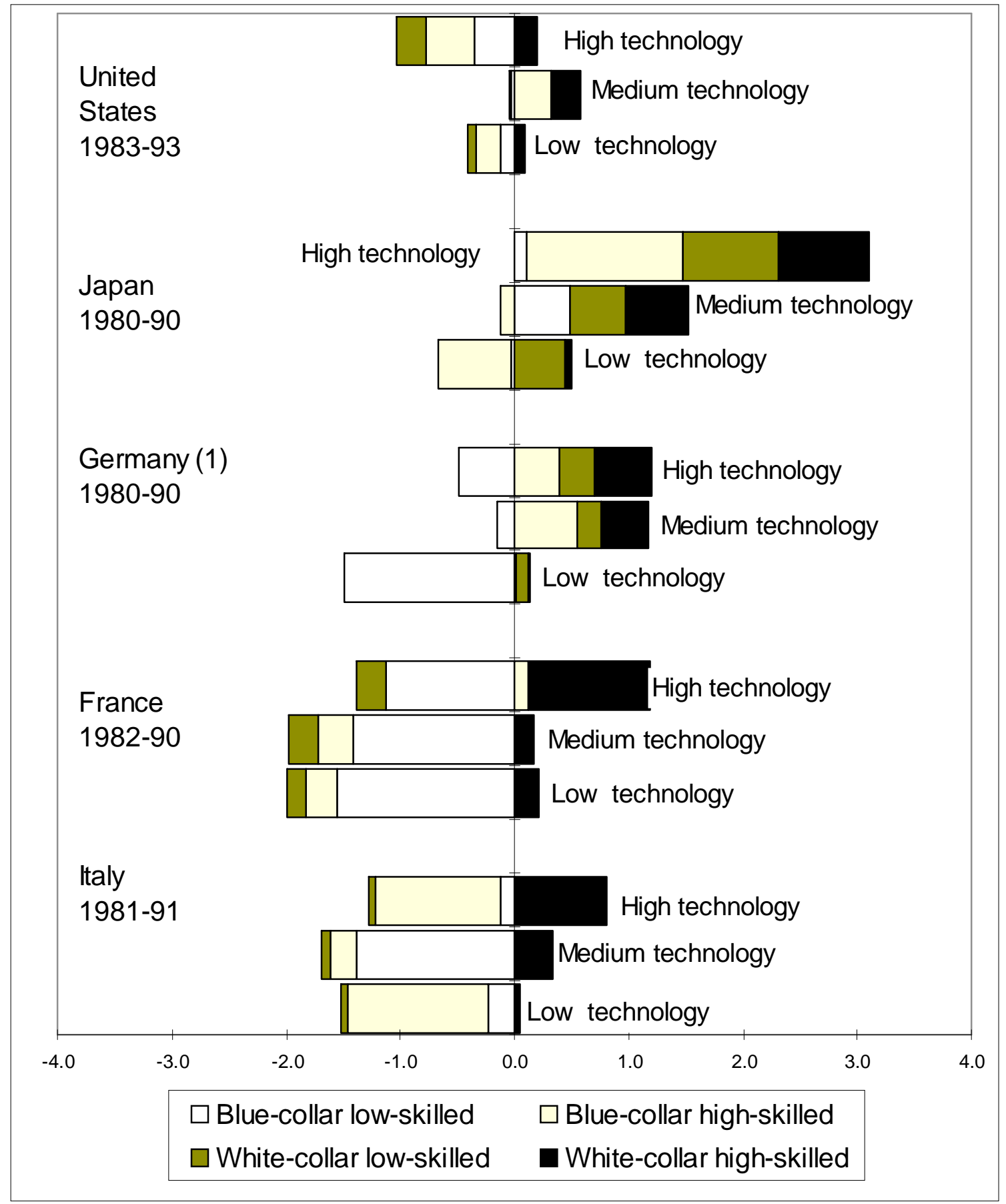

Note: See text for definitions.

1. The white-collar high-skilled group in Germany excludes some occupations and is thus underestimated. Source: OECD Secretariat calculations from national data; STI/EAS Division. 
Graph 7. Breakdown of services employment growth by occupations

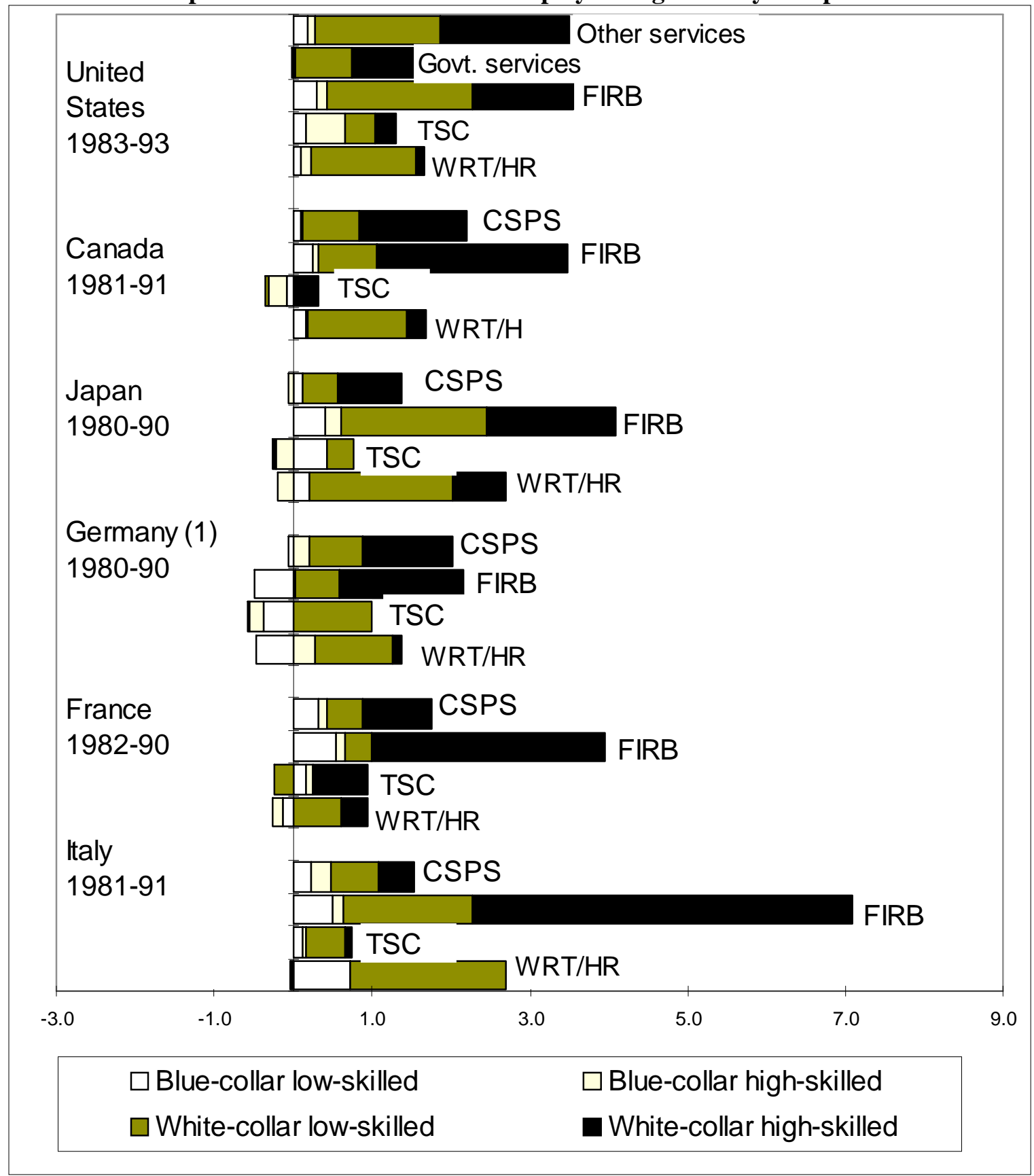

Note: See text for definitions; growth rates are annual average growth rates.

Abbreviations:WRT/HR: "Wholesale and retail trade, hotels and restaurants" (ISIC 6).

TSC: "Transport, storage and communications" (ISIC 7).

FIRB: "Finance, insurance, real estate and business services" (ISIC 8).

CSPS: "Community, social and personal services" (ISIC 9).

Source: OECD calculations from national data, STI/EAS Division. 


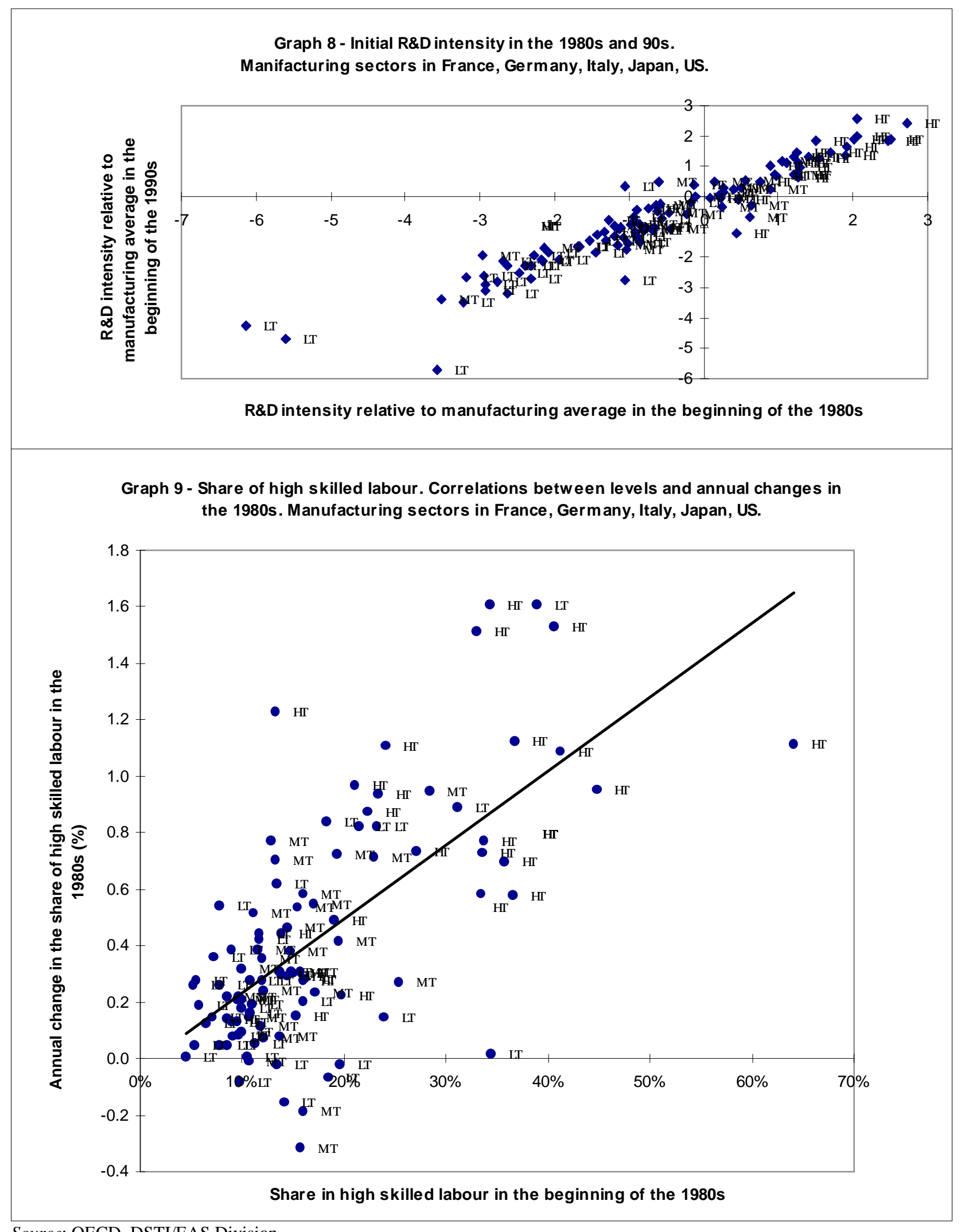

Source: OECD, DSTI/EAS Division. 


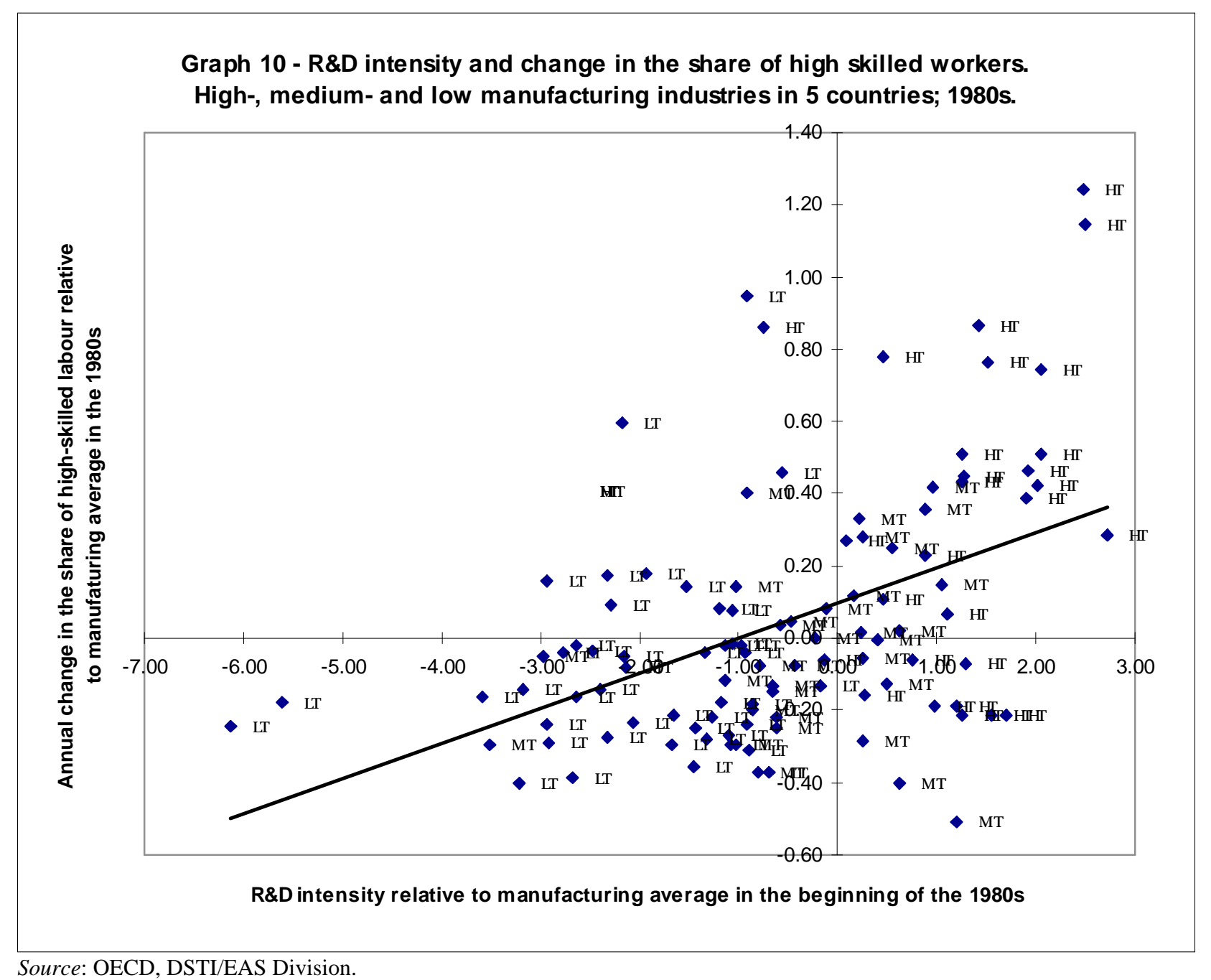

Source: OECD, DSTI/EAS Division. 
Table 1. Percentage of labour force with "high" and "low" education

\begin{tabular}{|c|c|c|c|c|c|c|c|}
\hline & & & $\begin{array}{l}\text { Annual } \\
\text { change }\end{array}$ & & & & $\begin{array}{l}\text { Annual } \\
\text { change }\end{array}$ \\
\hline United States & 1970 & 1991 & & Canada & 1975 & 1993 & \\
\hline High & 15.7 & 28.2 & 0.57 & High & 10.4 & 16.8 & 0.34 \\
\hline Low & 37.5 & 14.5 & -1.70 & Low & 23.3 & 7.3 & -2.16 \\
\hline Japan & 1971 & 1992 & & Netherlands & 1975 & 1993 & \\
\hline High & 16.8 & 36 & 0.87 & High & 10.2 & 23.9 & 0.72 \\
\hline Low & 48.6 & 22 & -1.32 & Low & 72.8 & 33.1 & -2.70 \\
\hline Germany & 1978 & 1987 & & Australia & 1979 & 1993 & \\
\hline High & 9.6 & 12.8 & 0.32 & High & 7.7 & 12.7 & 0.33 \\
\hline Low & 20.5 & 15.6 & -1.17 & Low & 48.1 & 30.7 & -2.90 \\
\hline France & 1970 & 1993 & & Spain & 1976 & 1993 & \\
\hline High & 4.9 & 17.3 & 0.52 & High & 2.6 & 5.5 & 0.16 \\
\hline Low & 23.4 & 68.9 & 3.40 & Low & 75.8 & 40.4 & -9.08 \\
\hline United Kingdom & 1973 & 1991 & & Norway & 1972 & 1993 & \\
\hline High & 16.4 & 36.8 & 1.07 & High & 9.9 & 26.2 & 0.74 \\
\hline Low & 55.7 & 28.2 & -1.29 & Low & 64.5 & 16.3 & -2.79 \\
\hline Italy & 1977 & 1992 & & Sweden & 1971 & 1990 & \\
\hline High & 18 & 35.2 & 1.08 & High & 7.9 & 21.7 & 0.69 \\
\hline Low & 56 & 23.1 & -1.81 & Low & 59.7 & 30.6 & -1.97 \\
\hline
\end{tabular}

Definitions for "high" and "low" education and sample:

1. United States: Low: less than four years of high school; high: four or more years of college. Males 25-64.

2. Japan: Low: junior high school; high: university. Males 16-64.

3. Germany: (West only) Low: production and related workers, transport equipment operators, and labourers; high: professional, technical, and related administrative and managerial workers. Males.

4. France: Low: primary school certificate or less; high: at least two years of university. Males $15+$.

5. UK: Low: no qualifications; high: A levels, professional qualification, or university degree. Males 16-64.

6. Italy: Low: lower secondary or less; high: upper secondary or higher. Males 16-64.

7. Canada: Low: up to level 8; high: university degree. Males $15+$.

8. Netherlands: Low: basic education, completed junior secondary school, or junior vocational training; high: completed vocational college or university education. Males 15-64.

9. Australia: Low: did not attend highest level of secondary school; high: university degree. Males 15-69.

10. Spain: Low: illiterate or without primary studies; high: essentially university (superior). Males 16-64.

11. Norway: Low: primary level; high: university level. Males and females, 16-74.

12. Sweden: Low: pre-upper secondary school up to ten years; high: post-upper secondary education. Males 16-64. Source: Nickell and Bell (1995) and OECD (1994b). 

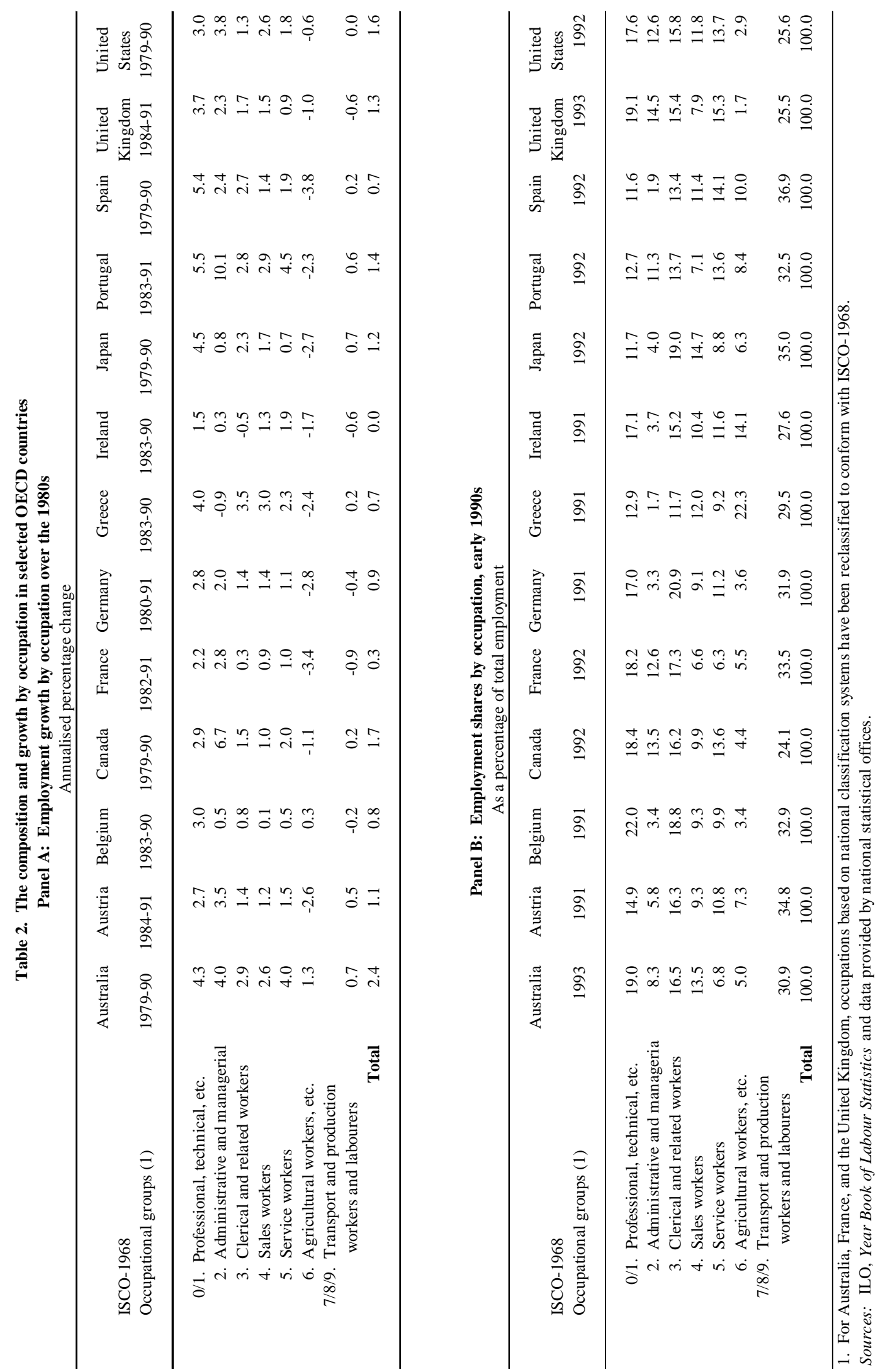
Table 3. Decomposition of changes in high-skilled employment ${ }^{1}$

\begin{tabular}{|c|c|c|c|c|c|c|}
\hline & Period & & $\begin{array}{l}\text { Total annualised } \\
\text { change in the share } \\
\text { of high-skilled } \\
\text { employment }\end{array}$ & $\begin{array}{c}\text { Between } \\
\text { industry } \\
\text { component }\end{array}$ & $\begin{array}{c}\text { Within } \\
\text { industry } \\
\text { component }\end{array}$ & $\begin{array}{c}\% \\
\text { contribution } \\
\text { of within } \\
\text { industry } \\
\text { component }\end{array}$ \\
\hline \multirow[t]{3}{*}{ United States } & $1983-93$ & TOTAL & 0.22 & 0.05 & 0.17 & 78.3 \\
\hline & & Manufacturing & 0.19 & -0.02 & 0.21 & 91.9 \\
\hline & & Market services & 0.25 & 0.03 & 0.22 & 86.3 \\
\hline \multirow[t]{2}{*}{ Canada $^{2}$} & 1981-91 & $\begin{array}{l}\text { TOTAL } \\
\text { Manufacturing }\end{array}$ & 0.48 & 0.07 & 0.41 & 84.5 \\
\hline & & Services & 0.37 & 0.10 & 0.27 & 72.2 \\
\hline \multirow[t]{3}{*}{ Japan } & $1980-90$ & TOTAL & 0.36 & 0.09 & 0.26 & 73.6 \\
\hline & & Manufacturing & 0.21 & 0.02 & 0.19 & 88.7 \\
\hline & & Market services & 0.27 & 0.04 & 0.23 & 84.9 \\
\hline \multirow[t]{3}{*}{ France } & $1982-90$ & TOTAL & 0.62 & 0.26 & 0.36 & 58.4 \\
\hline & & Manufacturing & 0.66 & 0.05 & 0.61 & 92.4 \\
\hline & & Market services & 0.45 & 0.08 & 0.37 & 82.0 \\
\hline \multirow[t]{3}{*}{ Italy } & $1981-91$ & TOTAL & 0.34 & 0.21 & 0.13 & 38.7 \\
\hline & & Manufacturing & 0.37 & 0.01 & 0.35 & 96.2 \\
\hline & & Market services & 0.06 & 0.11 & -0.05 & 31.2 \\
\hline \multirow[t]{3}{*}{ Australia } & 1986-91 & TOTAL & 0.22 & -0.06 & 0.27 & 83.0 \\
\hline & & Manufacturing & 0.56 & 0.01 & 0.54 & 97.4 \\
\hline & & Market services & 0.47 & 0.09 & 0.38 & 81.3 \\
\hline \multirow[t]{3}{*}{ New Zealand } & $1976-90$ & TOTAL & 0.96 & 0.19 & 0.77 & 80.1 \\
\hline & & Manufacturing & 0.38 & -0.02 & 0.40 & 95.4 \\
\hline & & Market services & 1.06 & 0.16 & 0.90 & 85.2 \\
\hline
\end{tabular}

1. The following breakdown is performed: $\Delta \mathrm{P}(\mathrm{j})=\Sigma \Delta \mathrm{S}(\mathrm{i}) \mathrm{P}(\mathrm{sj})+\Sigma \Delta \mathrm{P}(\mathrm{sj}) \mathrm{S}(\mathrm{i})$, where $\mathrm{i}$ indicates industry, $\mathrm{j}$ represents skill level, $S$ is the share of total employment, and $P(j)$ is the proportion of workers of skill type $j$.

2. No disaggregation for the manufacturing sector available.

Source: OECD calculations. 
Table 4 - Upskilling and technology: cross-sector regressions (France, Italy, Japan, US, Germany)

\begin{tabular}{lccccccc} 
IKI & GRP & RDI & RDI $_{(\mathrm{HT})}$ & RDI $_{(\mathrm{MT})}$ & RDI $_{(\mathrm{LT})}$ & DoF & Rbar**2 \\
0.17 & 0.02 & 0.17 & & & & 75 & 0.51 \\
$(2.47)$ & $(3.87)$ & $(4.19)$ & & & & & \\
0.13 & 0.01 & & 0.63 & 0.2 & 0.15 & 73 & 0.43 \\
$(2.51)$ & $(1.94)$ & & $(4.46)$ & $(2.05)$ & $(2.42)$ & & \\
\hline
\end{tabular}

Sample: 22 STAN manufacturing sectors, 5 countries, 1980-90. Dependent variable: annual change in the share of white-collar high-skilled workers in the 80s. Regressors: IKI = beginning of the period capital-labour ratio, GRP $=$ annual growth rate in the number of patents, RDI = beginning of the period R\&D expenditure as a share of production. Heteroscedastic consistent $\mathrm{t}$-values in parenthesis. All variables are expressed relative to manufacturing average. Constant, dummies and correction for outliers in each regression.

Table 5 - The growth rate of high skilled workers in the 80s: cross-sector regressions (France, Italy, Japan, US, Germany)

\begin{tabular}{|cccccccc|}
\hline$\Delta \log L P T Y$ & $\Delta \log$ VA & $\Delta \log P$ & $\operatorname{logRDT}$ & $\operatorname{logRDIO}(\mathbf{1})$ & $\operatorname{logRDIMI}(\mathbf{2})$ & DoF & Rbar**2 \\
& & & & & & 61 & 0.68 \\
-0.60 & 0.34 & 0.06 & 0.24 & & & & \\
$(8.9)$ & $(5.12)$ & $(1.72)$ & $(2.06)$ & & & & \\
-0.60 & 0.44 & 0.06 & & 0.71 & 1.04 & 68 & 0.66 \\
$(9.72)$ & $(6.07)$ & $(1.45)$ & & $(2.83)$ & $(4.70)$ & & \\
-0.59 & 0.47 & $0.07(3)$ & & 0.81 & 0.99 & 68 & 0.67 \\
$(9.27)$ & $(6.55)$ & $(1.93)$ & & $(3.32)$ & $(4.86)$ & & \\
\hline
\end{tabular}

Sample: 22 STAN manufacturing sectors, 5 countries, 1980-90. Dependent variable: growth rate of white collar-high skilled workers. Regressors: $\mathrm{LPTY}=$ labour productivity, $\mathrm{VA}=$ value added, $\mathrm{P}=$ the number of patents granted, $\mathrm{RDT}=$ direct plus embodied R\&D expenditure as a share of production. $\mathrm{RDIO}=$ direct $\mathrm{R} \& \mathrm{D}$ intensity, $\mathrm{RDIMI}=\mathrm{R} \& \mathrm{D}$ intensity embodied in imported intermediates. Annual growth rates in the $80 \mathrm{~s}$, levels at the beginning of the period. Heteroscedastic consistent t-values.in parenthesis. (1) coefficient significant for HT sectors, (2) coefficient significant for LT sectors, (3) Japan excluded. All variables are expressed relative to manufacturing average. Constant, dummies, correction for outliers in each regression. 


\section{STI WORKING PAPERS}

1. Embodied Technology Diffusion: An Empirical Analysis for 10 OECD Countries George Papaconstantinou, Norihisa Sakurai and Andrew Wyckoff

2. The Impact of R\&D and Technology Diffusion on Productivity Growth: Evidence for 10 OECD Countries in the 1970s and 1980s

Norihisa Sakurai, Evangelos Ioannidis and George Papaconstantinou

3. Short-term Indicators: Using Qualitative Indicators to Update Production Indices

Paul Schreyer and Corinne Emery

4. SMEs and Employment Creation: Overview of Selected Quantitative Studies in OECD Member Countries

Paul Schreyer

5. Globalisation and Competitiveness: Relevant Indicators

Thomas Hatzichronoglou

6. Factors Influencing the Steel Work Force: 1990 to 1995

Donald F. Barnett

7. Measuring R\&D in the Services

Alison Young

8. The Evolution of Skills in OECD Countries and the Role of Technology

A. Colecchia and G. Papaconstantinou 